\title{
Pancreatic Beta Cell Tumors
}

\author{
M. Isabel del Olmo시 J. Francisco Merino-Torres ${ }^{1}$, \\ J. Luis Ponce ${ }^{2}$ and Angel Moya ${ }^{2}$ \\ ${ }_{1}$ University Hospital La Fe-Valencia \\ Department of Endocrinology and Nutrition \\ ${ }^{2}$ Department of Surgery \\ Spain
}

\section{Introduction}

Hypoglycemia is a common syndrome. The manifestations of hypoglycemia are nonspecific, vary among individuals and may change from time to time in the same individual. They are also typically episodic. Thus, although the clinical history is of fundamental importance in suggesting the possibility of hypoglycemia, the diagnosis cannot be made solely on the basis of symptoms and signs.

The vast majority of instances hypoglycemia is secondary to treatment of diabetes. Only a minority of the cases are due to other relatively unfrequent causes. In practice, the most common initial questions are whether the patient truly has hypoglycemia, and if it is likely to be reactive or whether there are grounds for considering insulinoma or islet hyperplasia. The clinical and physiopathological features, diagnosis and treatment of pancreatic beta cell tumors will be discussed in the following chapter.

\section{Historical data}

Low blood glucose concentrations were first described in the 19th century as a feature of several diseases. The islets of Langerhans were discovered in 1869 and were named after the German pathologist Paul Langerhans who discovered regions within the pancreas that produced hormones. Nicholls first described in the findings of an autopsy an islet cell tumor in 1902. In 1922 Banting and Best discovered insulin; however, it was not until insulin became available for the treatment of diabetes mellitus in the early 1920s that clinical events similar to those arising from overtreatment with insulin were identified in nondiabetic patients. In 1923, Campbell and Fletcher were the first to describe the hypoglycemic complex due to an insulin excess in non-diabetic patients.

The first resection of an insulinoma was performed in 1927, when WJ Mayo removed an insulin-secreting tumor from a physician and injected it into rabbits that developed subsequently hypoglycemia. In 1938, Whipple reported a triad, considered pathognomonic for insulinoma: blood glucose levels less than $50 \mathrm{mg} / \mathrm{dL}$, neurologic symptoms of hypoglycemia and immediate alleviation of symptoms after glucose ingestion. In 1954, Wermer described a family with a syndrome often associated with pancreatic and other neuroendocrine tumors, the multiple endocrine neoplasia type 1 (MEN1). In 1993, 
Gagner et al. reported the first successful laparoscopic distal pancreatectomy and pancreatoduodenectomy. The first successful laparoscopic resection for pancreatic insulinoma was made in 1996.

\section{Clinical spectrum of pancreatic beta cell tumors}

Pancreatogenous hypoglycemia is a syndrome characterized by endogenous hyperinsulinemic hypoglycemia that comes from a pancreatic beta-cell malfunction. This malfunction can exist as a tumoral mass or a hyperplasia.

Pancreatic beta-cell tumors usually appear as a well-defined mass producing insulin named insulinoma. Commonly insulinomas are sporadic although a low percentage of them are associated with inherited diseases. Another small percentage are not tumoral, but a hyperplasia of beta cells or nesidioblastosis which develop a similar syndrome to insulinomas but with different pathological appearance and therapeutic management.

\subsection{Sporadic insulinoma}

Insulinomas are so rare that few institutions have accrued enough experience to provide meaningful data regarding epidemiological or demographic characteristics. The estimated incidence of insulinomas in the general population is estimated 1-4 per 1,000,000 yearly. However, the incidence has been reported higher in autopsy studies (0.8-10\%), suggesting that these tumors frequently remain undiagnosed. The mean age of patients at presentation is between 47-50 years, patients with MEN 1 are usually younger. In most series, females show a discrete predominance over men (ratio 1.5-1:1).

Insulinomas comprise $70 \%$ to $80 \%$ of all functional neuroendocrine pancreatic tumors. The majority are solitary, benign lesions occurring in a sporadic setting; they are also single , small and hypervascular, with $90 \%$ measuring less than $2 \mathrm{~cm}$ and $30 \%$ measuring less than 1 $\mathrm{cm}$ in diameter; approximately $10 \%$ are multiple.

Malignant insulinomas represent about $10 \%$ of all insulinomas. Contrary to benign ones, malignant are more frequent in men.

Insulinomas have a lower malignancy rate than other islet cell tumors such as gastrinomas and glucagonomas. It is very difficult to distinguish between malignant and benign insulinomas since endocrine tumors show frequently mild nuclear and structural atypia. Moreover, malignant insulinomas are usually diagnosed intrasurgically or by an image evidencing liver metastases, regional nodes or local invasion.

However, malignant insulinomas, which are solitary and have no evidence of metastases, usually have a better prognosis. Several studies have been performed to investigate the mean survival of a metastatic insulinoma that has been established in 2.6 years since diagnosis (1.6-7.5) (Starke et al., 2005).

\subsection{Multiple endocrine neoplasia type 1}

Multiple endocrine neoplasia type 1 is an autosomal dominant predisposition to tumors of the parathyroid glands, pancreatic islet cells and anterior pituitary; hence the mnemonic device of the " 3 Ps". However, the clinical spectrum of this disorder has been expanded.

A consensus statement from an international group of endocrinologists recommends that MEN1 is defined as the presence of two of the three main MEN1 tumor types (parathyroid, entero-pancreatic endocrine adenomas, and pituitary adenomas). Familial MEN 1 is defined 
as an index MEN1 case with at least one relative who has one of the three main MEN1 tumors. (Brandi, ML et al, 2001)

Effective treatment is usually available for hyperparathyroidism and pituitary disease; the malignant potential of pancreatic endocrine tumors is the primary life-threatening manifestation of MEN1. Functioning pancreatic islet cell or gastrointestinal endocrine cell tumors become clinically apparent in approximately one third of patients with MEN1. The most common cause of symptomatic disease is the Zollinger-Ellison (gastrinoma) syndrome (ZES), leading to multiple peptic ulcers. Symptomatic insulinomas also occur with moderate frequency, while VIPomas and glucagonomas are rare.

Insulin-producing pancreatic islet cell adenomas in MEN1 represent about $10 \%$ of the totality of insulinomas. They are often small, may be multiple, and may be associated with the simultaneous presence of other islet cell tumors. The diagnosis of insulinoma depends, as in nonfamilial causes, upon the documentation of hypoglycemia with characteristic symptoms that are rapidly reversed by the administration of glucose, and inappropriately high serum insulin concentrations.

Approximately 4 to 10 percent of patients with insulinoma have MEN1, and in most of them the MEN1 is known or suspected. Treatment is complicated in these patients by the possible presence of multiple insulinomas, the likelihood that preoperative or intraoperative location techniques may miss small tumors and the continuing risk of recurrence of pancreatic tumors after surgery. As a result, some experienced surgeons recommend local excision of any tumors found in the head of the pancreas plus a distal subtotal pancreatectomy. This approach differs from that in patients with sporadic insulinomas, who typically have a solitary tumor and in whom the localization and local excision alone are usually successful. In a cohort study of therapeutical response, patients who required additional surgical treatment because of failed initial surgery or recurrence of insulinoma over the period 1927 to 1986 had an increased prevalence of MEN 1 with multiple tumors (25\%) and malignant insulinomas (13\%).(Service, FJ, et al. 1991)

The inheritance of classical MEN1 follows an autosomal dominant pattern. Genetic linkage analysis implicated a region on the long arm of chromosome 11 (11q13) as the site of "MEN1 gene" in 1988. In 1997 the candidate gene was found, the MEN 1 gene, whose protein product is termed "menin" was mutated in 14 of 15 families with MEN1.

Much has been learned about the biochemical and cellular functions of menin, but the precise way in which these functions relate with the tumorigenesis is still not well established. However, it is clear that most of the MEN1 gene mutations found in MEN1 patients would be expected to inactivate or disrupt menin function.

\subsection{Noninsulinoma pacreatogenous hypoglycemia or nesidioblastosis}

Noninsulinoma pancreatogenous hypoglycemia or nesidioblastosis is a syndrome characterized by endogenous hyperinsulinemic hypoglycemia that is not caused by an insulinoma which accounts for most cases of hyperinsulinemic hypoglycemia. Nesidioblastosis is the name given to the presence of islets in intimate association with ducts, leading to the formation of so-called ductulo-insular complexes.

Nesidioblastosis has mainly been described in neonates. Since Harness et al first described nesidioblastosis in adults, it has been reported in association with other diseases, such as Zollinger-Ellison syndrome, multiple endocrine adenomatosis, $\beta$-cell adenomatosis, 
Lindau's disease, bariatric surgery, cystic fibrosis, insulinomas, pancreatic transplantation, orbital lymphoma with hypopituitarism and adrenal insufficiency, familial adenomatous polyposis, hypergastrinemia, and pancreatic polypeptidemia.(Abellán, P., et al. 2008).

Sporadic hyperinsulinemic hypoglycemia is the main clinical feature of nesidioblastosis and the diagnostic proceedings are the same as those of insulinoma. However, therapeutic management differs as the extension of the disease in the pancreatic gland may be diffuse.

\section{Pathogenesis}

Insulinomas are the most frequent functioning endocrine pancreatic tumors. The etiology of these kinds of tumors is poorly understood until the moment. Some tumors may harbor MEN 1 gene mutations, the susceptibility gene of the MEN 1 syndrome, but most cases show wild type MEN 1. While those tumors originated in the exocrine pancreas have been attributed to environmental risk factors and certain mutations, in those from the endocrine pancreas the evidence is quite limited.

In order to improve the diagnosis, prognosis and therapy of insulinoma patients, it is important to increase our understanding of the molecular processes underlying tumor development and progression. During tumorigenesis in general an alteration in the cell physiology takes place as a result of an accumulation of genetic alterations which lead to an uncontrolled cell growth, tissue invasion and metastatic spread. The knowledge of these molecular alterations permits us a focused molecular treatment in these tumors, especially in those with a greater malignant potential.

Therefore, a brief revision of the possible alterations which lead to tumorigenesis in the sporadic insulinoma will be discussed. The altered cellular phenotype in these tumors may involve different genes and mutations which participate in self-sufficiency growth signals, insensitivity to growth-inhibitory signals, evasion of programmed cell death (apoptosis), unlimited replicative potential, sustained angiogenesis and tissue invasion. It is also important to consider that the mechanisms involving MEN 1 insulinoma development and sporadic insulinoma are not the same (Jonkers, JMH et al. 2007) (figure 1).

\subsection{Menin molecular interactions}

The MEN 1 gene was the first gene described as a candidate gene implicated in insulinoma tumorigenesis. Several studies have been performed which suggest a minor role for MEN 1 inactivation by mutation in human sporadic insulinomas. Menin, the 610 aminoacid protein encoded by MEN1 has been found to partner in vitro with a variety of proteins that comprise transcription factors, DNA processing factors, DNA repair proteins and cytoskeletal proteins. The role of menin inactivation in tumorigenesis, which takes place in the MEN type 1, is diverse participating in mechanisms of failure in DNA repair (via FANCD2), transcription and proliferation (via p27/p18), switching growth suppression to growth proliferation (via JunD), functional stimulation of S-phase kinase and essential component for the S-phase entry, transcriptional activation of NFKB which inhibits apoptosis and stimulates cell growth or neutralizing cell growth inhibition through SMAD3.

Although this inactivation only occurs rarely in sporadic insulinomas, studies which focus on the molecular alterations of menin interacting proteins should be developed. 


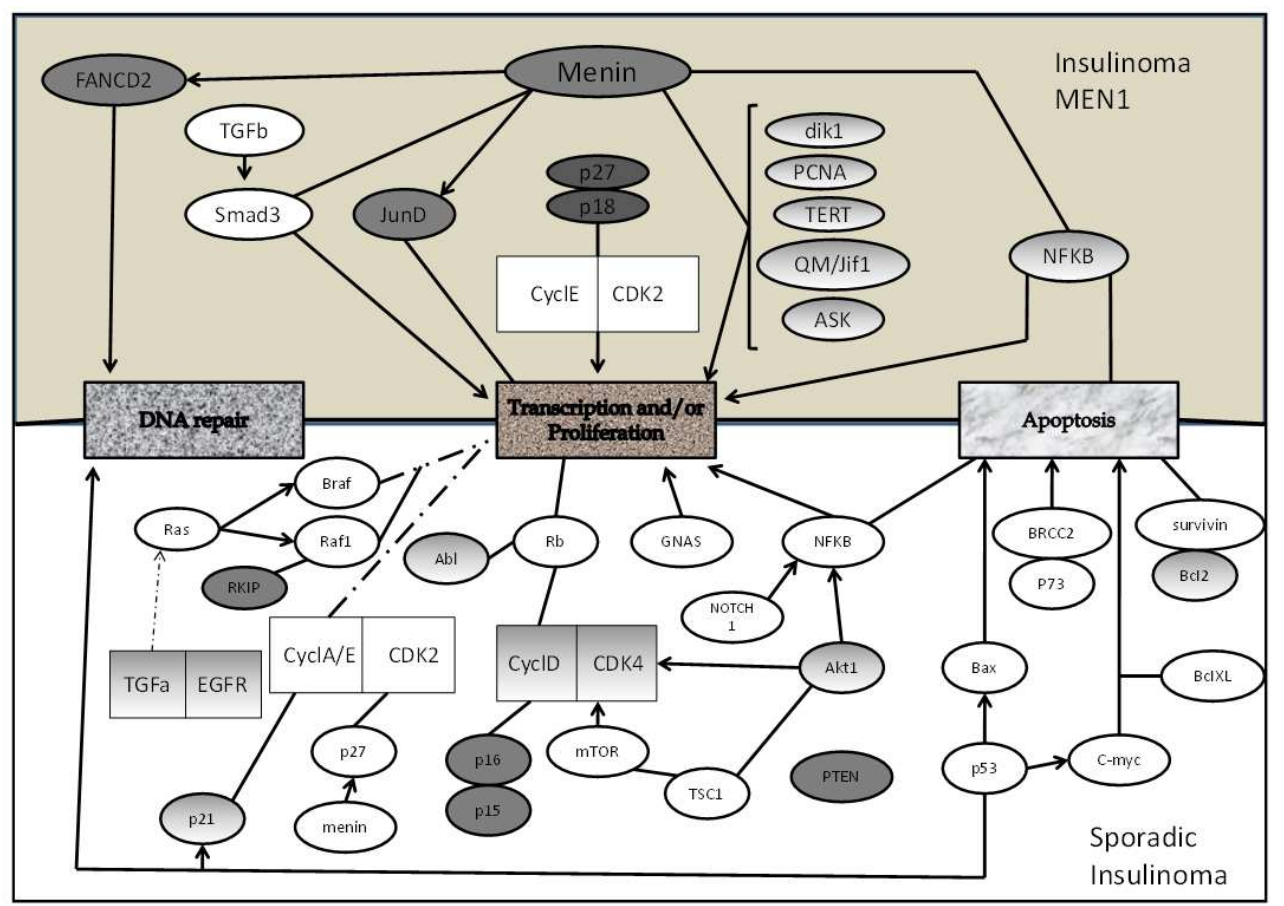

Fig. 1. Signaling molecules and paths that may be involved in insulinoma tumorigenesis. The upper part (shaded in grey) represents those which participate in MEN 1 and the lower part (white) those in sporadic insulinoma. Those whose role have been suggested but not confirmed are in white, those with a loss of function are in grey and those with a gain are shaded. (Adapted from Jonkers, YMH. et al. 2007)

\subsection{Self-sufficiency in growth signals}

Cell cycle deregulation is one of the defining features of cancer. The roles of several proteins have been suggested to stimulate cell proliferation in insulinomas.

Cyclin dependent kinase 4 (CDK4) together with its regulatory subunit cyclin D governs cell cycle progression through G1 phase. The deregulation of this complex has been studied in islet $\beta$-cell proliferation. Several studies show that knock-in mice with an homozygous CDK4 mutation develop multiple neoplasia, most commonly endocrine tumors, including benign insulinomas. However, CDK4 mutations have not been detected in sporadic human insulinomas neither a significantly altered expression of CDK4. On the other hand, overexpression of cyclin D1 has been observed in benign insulinomas compared to normal pancreatic islets, suggesting that this oncogene is involved at least in the tumorigenesis in a certain subgroup of these tumors.

The Akt 1 gene has also been described to induce $\beta$-cell proliferation via CDK4 by increasing cyclin D1 and D2 levels. Transgenic mice which overexpress a constitutively active form of Akt 1 in islet beta cells exhibit striking increases in $\beta$-cell mass, proliferation, cell mass and malignant tumor formation. The Akt 1 gene is located on a region which has often found to be gained in insulinomas of malignant behavior. One of the growth factors which seems to 
trigger the PI3K/Akt pathway is the insulin-like growth factor receptor. Several components of the IGF system show differences in mRNA expression suggesting a prominent role of this system in growth promotion. This pathway has been extensively explored and is one of the molecular targets being used recently in malignant insulinomas. Everolimus is an orally derivative of rapamycin that inhibits Ser/Thyrosine kinase, the PI3k/Akt/mTOR pathway.

A gene expression profiling study described the GNAS gene (guanine nucleotide binding protein alpha subunit) as the most highly expressed gene in insulinomas compared to normal pancreatic tissue. It is also well established that activating mutations of the gene encoding GNAS can stimulate proliferation of endocrine cells and are involved in the pathogenesis of several tumors. The underlying method of this up regulation is still unknown and until now no mutations of this gene have been identified in human insulinomas.

TGF $\alpha$ (transforming growth factor $\alpha$ ) has been associated with the development of insulinomas. Immunohistochemistry showed its expression already in benign tumors and enhanced expression in malignant insulinomas. TGF $\alpha$ secreted by tumor cells can bind to the epidermal growth factor receptor (EGFR) leading to an autocrine activation of the Ras signaling pathway and putatively to its oncogenic activity. EGFR is located in chromosome $7 \mathrm{p} 12$, gained in $8 \%$ of benign versus $89 \%$ of malignant insulinomas, thus, speculating an involvement in the malignant progression of insulinomas.

Recent studies have also shown that gain of chromosome $9 q$ is one of the earliest aberrations in insulinoma development. FISH analysis showed multiple copies of cAbl gene in these tumors including cases with amplification. cAbl tyrosine kinase gene is a proto-oncogene with growth promoting activity. Overexpression of cAbl by means of RT-PCR and inmuhistochemistry were found suggesting and early role in some subgroups of insulinomas.

In conclusion, several proteins involved in self-sufficiency cell growth, including cyclin D, Akt 1, GNAS, TNF $\alpha$ and cAbl have been suggested to stimulate cell proliferation in insulinomas, although their individual roles still remain elusive.

\subsection{Insensitivity to anti-growth signals}

Within a normal tissue, multiple antiproliferative signals operate to maintain cellular quiescence and tissue homeostasis. Cancer cells must evade these anti-proliferative signals if they are to prosper.

At the molecular level, many antiproliferative routes are controlled by the retinoblastoma protein $(\mathrm{pRb})$. In tumors with $\mathrm{pRb}$ inactivation as the basis of pathology somatic loss of one $\mathrm{Rb}$ allele commonly accompanies a point mutation or micro-deletion of the other allele. Deletion of $\mathrm{Rb}$ gene has so far been detected only in one human insulinoma. However, other mechanisms of inactivations of $\mathrm{pRb}$ are phosphorylation, but studies done until the moment conclude that $\mathrm{pRB}$ may not be strictly involved in de initiation of insulinomas.

CDKN2 locus on chromosome 9p21 harbors tumor suppressor genes which restrain cell growth by affecting the function of $\mathrm{pRb}$ and $\mathrm{p} 53$. Downregulation of expression of CDKN2A/p16, CDKN2B/p15 and CDKN2D/p14 have been studied. Absence of expression of p15 was detected in $33 \%$ of benign insulinomas. On the other hand, a low frequency of alterations were detected in p16 but a down-regulation of p16 protein was detected and it is likely to be involved in insulinoma tumorigenesis. Two other inhibitors of CDK2, p21 and p27 have been studied. P27 was expressed in 88\% of insulinomas, including malignant tumors but was also expressed in normal pancreatic islet cells. The strong expression of p21 and p27 may explain the slow growth in a subset of tumors and suggests differences in tumorigenesis between MEN1-associated and sporadic insulinomas. 
The Raf-1 kinase inhibitory peptide (RKIP) binds to Raf-1 and MEK in vivo and in vitro, thus interfering with the activation of the ERK signaling pathway, and plays an important role in the inhibition and beta-cell proliferation. Expression of RKIP was studied in insulinomas showing an absence of expression in comparison with normal islet cells.

PTEN (phosphatase with tensin homology) is a potent negative regulator of the PI3K/Akt signaling pathway. The PTEN gene is located on chromosome 10q23 a region which is often lost in malignant insulinomas. Loss of PTEN has been associated with malignancy of insulinomas, as it was not observed in benign insulinomas.

In conclusion, evading antiproliferative signals, for example through inactivation of $\mathrm{pRb}$, p15, p16 and/or PTEN may be important features involved in the development of insulinomas.

\subsection{Evading apoptosis}

The ability of tumor cell population to expand is not only determined by the rate of proliferation but also by the rate of cell death or apoptosis. Acquired resistance toward programmed cell death (apoptosis) is a hallmark of most types of cancer.

Certain apoptotic factors such as BcI-2 have been studied, and are frequently expressed in gastroenteropancreatic neuroendocrine tumors which are usually slow-growing and less aggressive tumors, suggesting that in these tumors BcI-2 expression leads to indolent tumor growth. Another factor such as c-Myc has also been demonstrated to induce highly malignant beta-cell tumors in mouse models. All this evidence suggests that suppression of apoptosis may contribute also to the initiation of these tumors.

Survivin, a member of another family of apoptosis inhibitors is a protein that can suppress apoptosis and regulate cell division. The gene encoding this protein, BIRC5, is located in chromosome 17q25 a region gained in one third of malignant insulinomas versus none of the benign insulinomas.

The P73 gene, encodes a protein with similar function to p53, and might be an interesting candidate for insulinoma progression. It is located on chromosome 1p36, a region that is deleted in $44 \%$ of malignant insulinomas and associated with metastasic disease.

In conclusion, due to the overall low proliferation rate in insulinomas, it is tempting to speculate that evasion of apoptosis is more important in their development instead of increased proliferation.

\subsection{Unrestricted replicative potential}

Human cells carry a cell-autonomous program that limits their multiplication. This program is independent from of the cell to cell signaling pathways. The progressive erosion of telomers during successive cycles of replication eventually causes cells to lose their ability to protect the ends of chromosomal DNA, which results letal to them.

Telomere maintenance is evident in virtually all types of malignant cells. For this purpose the malignant cells up-regulate the expression of telomerase enzymatic activity. Also stem cells do have a high telomerase activity. Because pancreatic stem cells are suggested as the clonal origin of insulinomas, telomerase activity may be expected in these tumors. This fact has not been demonstrated in sporadic insulinomas, however, in MEN1-associated insulinomas may play an important role.

On the other hand, telomeric loss has been shown by array to be associated with malignant behavior of insulinomas. In insulinomas with uncertain behavior telomeric losses were more 
frequently observed than chromosomal instability. This suggests that telomeric loss occurs prior to and is causative of chromosomal instability during insulinoma tumorigenesis. These data indicate that escape from replicative senescence, which is expected to occur as a result of telomeric loss, is the basis of tumor progression.

Therefore telomeric loss and chromosomal instability seem to accumulate during tumor progression and it is tempting to speculate that $\mathrm{p} 16$ down regulation and telomerase activity in addition ensure unrestricted replicative potential. Inactivation of menin may trigger activation of telomerase earlier in tumor development (MEN1).

\subsection{Sustained angiogenesis}

Tumorigenesis in general is critically dependent on the development of vascular supply. The fact that endocrine tumors are highly vascular in nature renders analysis of angiogenesis as a prognostic factor highly pertinent. However, in contrast to other cancers, a high vessel density in endocrine pancreatic tumors was found to correlate with good prognosis as well as with hormone production.

Endocrine pancreatic tumor cells overproduce the angiogenic peptide vascular endothelial growth factor (VEGF), which is likely to play an important role in the angiogenic process associated with endocrine tumorigenesis but they seem to lose this expression during tumor progression. In conclusion, although activation of angiogenesis is not indicated in tumor progression, it will be necessary to study additional angiogenic factors that may substitute loss of blood supply in insulinomas.

\subsection{Markers to predict metastasic disease and clinical outcome in insulinomas}

Certain markers such as CK-19 are associated with malignancy. Immunostaining of CK19 has resulted a reliable indicator of tumor-specific death in insulinomas. Also, chromosomal instability indentified by array has been detected as an optimal predictor of metastasic disease. Ki-67 $\geq 2 \%$ and p53 overexpression were found to be associated with malignancy in a few individual insulinoma cases.

\section{Histopathology}

Insulinomas exhibit four main histological patterns including: solid, trabecular, gland-like (tubular or acinar) and mixed forms. Larger tumors are encapsulated but the capsule is usually incomplete. Smaller tumors and microadenomas are rarely encapsulated. Tumor cells frequently exhibit a bland cytology and cells with large pleomorphic nuclei are rare. If present, these features are not predictive of malignant behavior. A relatively uncommon, but characteristic finding in insulinomas is the deposite of amyloid. Its major component is islet amyloid polypeptide or amylin that can be visualized by immunohistochemistry. Calcifications and intracytoplasmatic pigment may unfrequently be seen in insulinomas. (Figure 2)

The majority of insulinomas exhibit immunoreactivity for insulin and proinsulin. Insulinomas without any positive staining for insulin are also found indicating that the produced insulin is not stored inside the cells, but immediately released. In such cases, proinsulin staining or insulin messenger RNA in situ hybridization are valuable alternatives, but rarely used and more costly.

The byosinthesis of insulin takes place usually in the endoplasmic reticulum. In normal pancreatic beta-cells, proinsulin-insulin conversion occurs in acidic immature secretory 
granules of the trans-Golgi apparatus. In contrast to beta-cells, the proinsulin-insulin conversion in insulinomas occurs already in the Golgi apparatus, but remains incomplete, resulting in the formation of secretory granules containing both proinsulin and insulin.. The distribution pattern of proinsulin and insulin has been investigated and no correlation was found between a particular staining pattern, histological type, multihormonality or the degree of malignancy of insulinoma. (De Lellis, et al.2004).

Approximately $10-15 \%$ of insulinomas are classified as malignant on the basis of the presence of organ and/or lymph node infiltration or distant metastases. The most common sites of metastases for insulinomas are the peripancreatic lymph nodes with occasional hepatic metastases.

According to the WHO criteria histopathologically pancreatic neuroendocrine tumors (including insulinomas) should be classified into four groups (Komminoth, P. et al, 2004):

- Well differentiated endocrine pancreatic tumors in the absence of all adverse criteria

- Well differentiated endocrine pancreatic tumors of uncertain behavior: tumor diameter $>2 \mathrm{~cm},>2$ mitosis/10 high power fields, angioinvasion or a proliferative index Ki-67 > $2 \%$.

- Well differentiated endocrine pancreatic carcinomas: gross local invasion or metastases.

- Poorly differentiated pancreatic endocrine carcinomas: > 10 mitosis/ 10 high power field

Because these criteria are not always reliable, markers have to be detected to predict a possible malignant outcome of insulinomas in an earlier stage.

In the case of nesidioblastosis, the morphological criteria for establishing its diagnosis are the presence of differently-sized islets often with somewhat irregular outline, and irregularly sized and poorly defined endocrine cell clusters scattered in the acinar parenchyma and often intimately connected with small or large ducts (ductulo-insular complexes). Another feature is a distinct islet cell hypertrophy with nuclear enlargement, often resulting in the presence of giant and bizarre nuclei. Nesidioblastosis is classified into focal and diffuse types characterized by different clinical outcomes. Focal nesidioblastosis exhibits nodular hyperplasia of islet-like cell clusters, including ductuloinsular complexes and hypertrophied insulin cells with giant nuclei. In contrast, diffuse nesidioblastosis involves the entire pancreas with irregularly sized islets. (Figure 2)

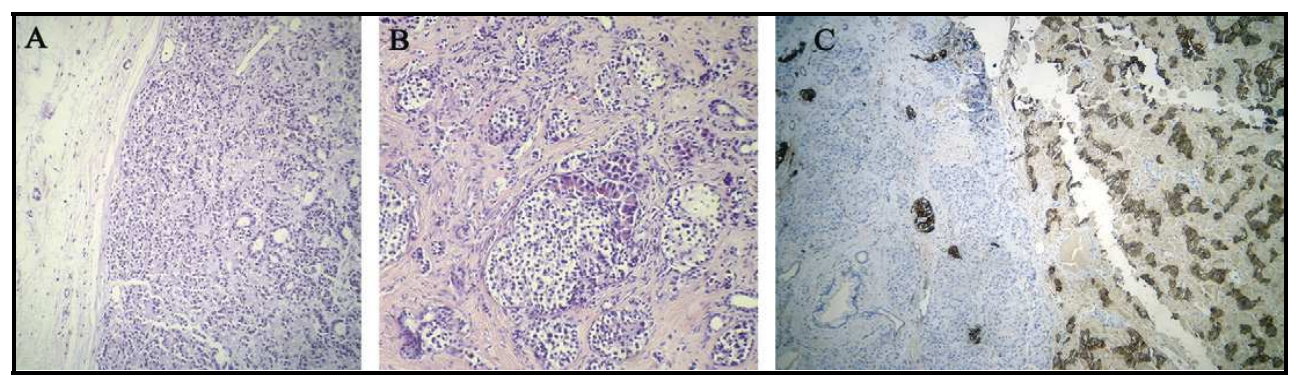

Fig. 2. Histopathological characteristics of insulinoma and nesidioblastosis. A. Insulinoma with peripancreatic fat. Haematoxylin and eosin (100x). B. Nesidioblastosis. Cluster of islets of varied size and shape in apposition to pancreatic ductules. Haematoxylin and eosin (250x). C. Insulin immunostaining showin insulinoma (right) with pancreatic tissue $(100 \mathrm{x})$. 


\section{Clinical features}

Insulinoma patients characteristically present at diagnosis with symptoms of hypoglycemia, especially neuroglycopenic symptoms that may or may not be preceded by symptoms due to sympathetic overdrive. The leading symptoms establishing the diagnosis of endogenous hyperinsulinism are comprised in the Whipple's triad. The neuroglycopenic symptoms of insulinomas include confusion, visual change, and unusual behavior. Neuroglycopenic symptoms are the direct result of central nervous system neuronal glucose deprivation. Neurogenic symptoms are the result of the perception of physiologic changes caused by the autonomic nervous system discharge triggered by hypoglycemia. Sympathoadrenal symptoms may include palpitations, diaphoresis and tremulousness. Amnesia for hypoglycemia is common in these patients. (Table 1)

This common clinical manifestation takes place usually in a fasting state. However, postprandial hypoglycemia may be a feature or even the sole manifestation of hypoglycemia in some patients. In retrospective reviews done to patients with confirmed insulinoma, $21 \%$ reported fasting and postprandial symptoms and $6 \%$ reported only postprandial symptoms (Placzkowski, KA, et al. 2009). The hypoglycemia in patients with insulinoma is primarily due to reduced hepatic glucose output rather than increased glucose utilization.

The mean duration of these symptoms before the diagnosis is established is less than 1.5 years. However, a few patients can be symptomatic for decades and can be misdiagnosed with a neurologic or psychiatric disorder. Clinical manifestations of an insulinoma can mimick central nervous system disorders, like epilepsy.

\begin{tabular}{|c|c|}
\hline Adrenergic symptomatology & Neuroglucopenic syptomatology \\
\hline & Confusion \\
Tremulousness & Letargy \\
Palpitations & Headache \\
Anxiety & Visual manifestations \\
Hunger & Fatigue, dizziness \\
Parestesias & Difficulty to talk \\
Hyperhidrosis/sweat & Unusual behavior \\
& Seizures \\
& Coma \\
& Death \\
\hline
\end{tabular}

Table 1. Hypoglycemic symptomatology.

\section{Diagnosis}

Neuroendocrine tumors (NETS) are rare, slow growing neoplasms characterized by their ability to store and secrete different peptides and neuroamines. Some of these substances cause specific clinical syndromes, whereas others may have elevated plasma or urine levels that are not associated with specific syndromes or symptom complexes.

The biochemical markers are those hormones or amines secreted by the neuroendocrine cells from which these tumors are derived. In the case of the insulinoma, derived from the beta pancreatic cells, the biochemical marker secreted is insulin which leads in excess, to an hypoglycemic syndrome.

The Whipple's triad is the cornerstone for the suspicion of an insulinoma, although other causes must be ruled out. 


\section{WHIPPLE'S TRIAD}

1. Hypoglycemia symptoms induced by fasting

2. Blood glucose $\quad<50 \mathrm{mg} / \mathrm{dL}+$ symptoms $<40 \mathrm{mg} / \mathrm{dL}$ regardless of symptoms

3. Relief of symptoms when glucose is raised to normal

Fig. 3. Whipple's triad

Clinical syndrome is therefore the first step that leads to the suspicion of an insulinoma.

\subsection{Laboratory confirmation}

The diagnosis of an insulinoma can be established by determining plasma proinsulin, insulin, c-peptide and glucose levels, which are usually performed during a 72-hour fast. It is important to realize that insulin levels are increasingly being determined by immunochemiluminiscent assays or specific immunoradiometric assays that do not crossreact with proinsulin and give lower values than that obtained with most insulin radioimmunoassay, which can affect the proposed criteria listed in many reviews for diagnosis, which were based on radioimmunoassay results.

There are six main criteria for the diagnosis of insulinoma: documented blood glucose levels of $45 \mathrm{mg} / \mathrm{dL}$ or less $(2.2 \mathrm{mmol} / \mathrm{L})$, concomitant insulin levels of $6 \mu \mathrm{U} / \mathrm{mL}$ or greater $(\geq 36$ $\mathrm{pmol} / \mathrm{L} ; \geq 3 \mu \mathrm{U} / \mathrm{mL}$ ), c-peptide levels $200 \mathrm{pmol} / \mathrm{L}$ or greater, proinsulin levels $5 \mathrm{pmol} / \mathrm{L}$ or greater, $\beta$-hydroxybutyrate levels $2.7 \mathrm{mmol} / \mathrm{L}$ or less and absence of sulfonylurea (metabolites) in the plasma and/or urine. (Table 2)

\begin{tabular}{|cc|}
\hline Biochemical tests & Confirmation of insulinoma \\
Plasma glucose & $<45 \mathrm{mg} / \mathrm{dL}$ \\
Insulin & $\geq 3 \mu \mathrm{U} / \mathrm{mL}$ \\
C-peptide & $\geq 200 \mathrm{pmol} / \mathrm{L}$ \\
Proinsulin & $\geq 5 \mathrm{pmol} / \mathrm{L}$ \\
$\beta$-hydroxybutyrate & $<2.7 \mathrm{mmol} / \mathrm{L}$ \\
\hline
\end{tabular}

Table 2. Main criteria for the diagnosis of insulinoma

Further controlled testing under supervision includes the 72-hour fast, which is the goldstandard criterion for establishing the diagnosis of insulinoma. Actually, $98 \%$ of the patients with insulinoma will develop symptomatic hypoglycemia within 72 hours. When the patient develops symptoms and the blood glucose levels are $<40(45) \mathrm{mg} / \mathrm{dL}$ or less $(<2.2$ $\mathrm{mmol} / \mathrm{L}$ ), blood should also be drawn for c-peptide, proinsulin and insulin, and the fast should be stopped. Failure in appropriate insulin suppression in the presence of hypoglycemia substantiates an autonomously secreting insulinoma.

\subsubsection{How to perform a fast test}

The 72-h fast test can be initiated at any hour and may be prolonged until 72-hours. It is important to date the onset of fast as well as the last ingestion of calories. During the whole test, the patient may only be allowed to drink calorie and caffeine free beverages. It is 
important to ensure that the patient is active during waking hours and in some cases some exercise can be recommended at the end of the fast if it resulted negative.

In the basal state with the initiation of the fast state a $6 \mathrm{~mL}$ extraction for glucose, insulin and c-peptide will be done. These measurements should be repeated every 12 hours with a previous measurement of capillary glucose at 12, 24, 36, 48, 60 and 72 hours and after exercise if it takes place.

The end of the fast will be when the patient presents signs and symptoms of hypoglycemia and plasma glucose is $<40 \mathrm{mg} / \mathrm{dL}$. In this moment blood glucose will be drawn as well as insulin and c-peptide. Hypoglycemia will not be reversed until the central laboratory confirms the glucose value or the patient is unconscious and has fits. The reversal of the hypoglycemia will be with the administrations of oral glucose or intravenous if needed (dextrose $40 \%$ 250mL).

At the end of the fast, a measurement of glucose, insulin, c-peptide and sulphonylurea screen (blood and urine spot), should be done. If the patient presents no symptoms during the fast, it can be finished with a 15-30 min exercise (for example brisk walk) around the hospital and re-measuring.

\subsubsection{Interpretation of a fast test}

$90 \%$ of insulinomas will present hypoglycemia before 72 hour fast and insulin will be inappropriately high in relation with glucose levels.(Figure 4)

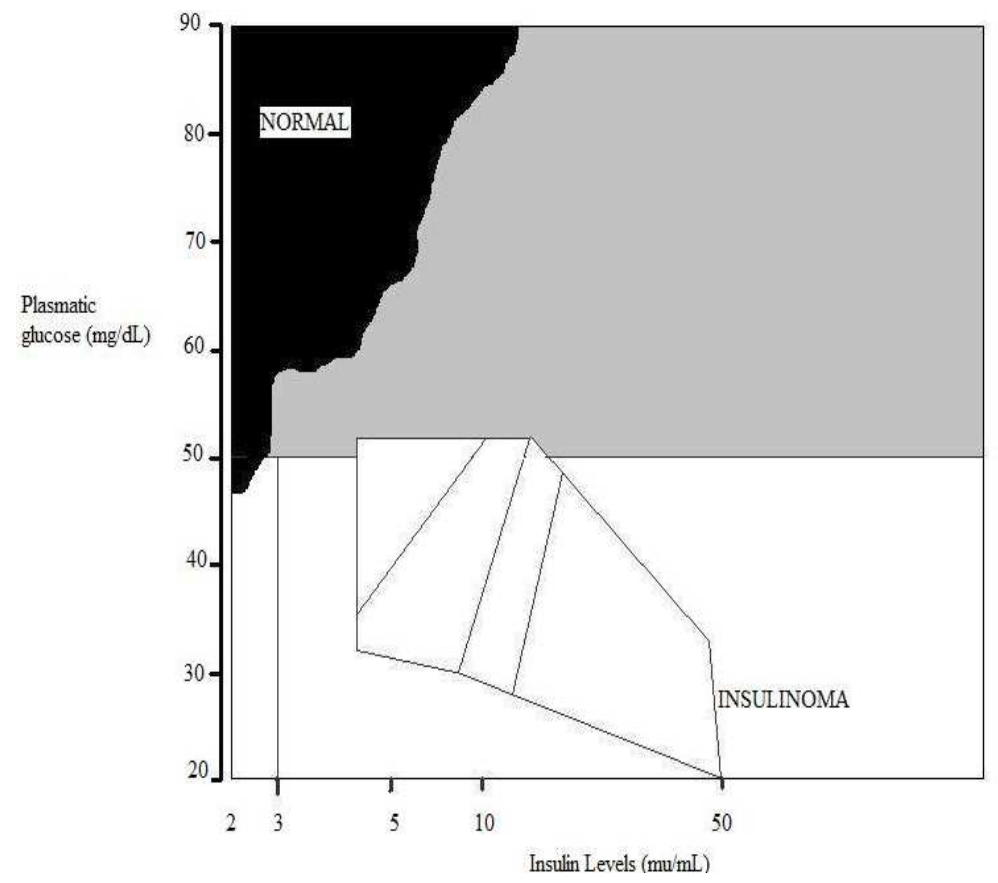

Fig. 4. Plasmatic insulin and glucose limits after a fast in normal subjects and patients affected of an insulinoma. The black area represents the normal response to hypoglycemia. The striped area represents the usual response in patients affected of an insulinoma. (Redrawn from Service, FJ. et al, 1999). 
Rare disorders, in which the biochemical findings simulate those of an insulinoma because they are also associated with endogenous hyperinsulinemia include administration of exogenous insulin or sulphonylureas and insulin autoimmune hypoglycemia.

The fast test permits us to differ between insulinoma, exogenous administration of insulin and sulphonylureas administration. If this last is suspected, urine and plasma collection of sulphonylureas should be performed. (Table 3)

\begin{tabular}{|c|c|c|c|c|}
\hline & Insulin & C-peptide & Proinsulin & Sulphonylureas \\
\hline $\begin{array}{c}\text { Exogenous } \\
\text { administration of } \\
\text { insulin }\end{array}$ & $\uparrow$ & $\downarrow$ & $\downarrow$ & NEGATIVE \\
\hline Insulinoma & 4 & $\uparrow$ & $\hat{T}$ & NEGATIVE \\
\hline $\begin{array}{c}\text { Exogenous } \\
\text { administration of } \\
\text { sulphonylureas }\end{array}$ & 4 & 4 & 4 & POSITIVE \\
\hline
\end{tabular}

Table 3. Differential diagnosis determined by the results of a fast test.

Insulin autoimmune hypoglycemia occurs in patients who have antibodies directed to endogenous insulin or to the insulin receptor. Symptoms can occur postprandially, fasting, or in both states. In patients with insulin autoantibodies, insulin secreted in response to a meal binds to the antibody and then disassociates in an unregulated fashion causing hyperinsulinemia and hypoglycemia. In patients with antibodies to the insulin receptor, hypoglycemia occurs as a result of antibody activation of the receptor. The presence of insulin or insulin receptor antibodies can distinguish insulin autoimmune hypoglycemia from insulinoma. The antibodies do not have to be measured during an episode of hypoglycemia.

\subsubsection{8 hour versus 72 hour fast}

It has been proposed that the sensitivity of the $48 \mathrm{~h}$ fasting test is between 94.5 and $95.7 \%$ and should be enough for the diagnosis of insulinoma instead of the 72-hour fast. In a series of 127 patients with insulinoma, the fast was ended due to hypoglycemia in $42.5 \%$ in 12 hours, $66.9 \%$ by 24 hours and $94.5 \%$ in 48 hours (Hirshberg, et al. 2000).

\subsubsection{Other laboratory tests}

\subsubsection{Intravenous secretin test for insulinoma}

In patients harboring and insulinoma, insulin production by normal pancreatic beta cells is significantly suppressed. Following intravenous injection of secretin ( 2 units/ $\mathrm{kg}$ of body weight), plasma insulin rises more than $200 \%$ in normal individuals, whereas in patients 
with insulinoma, the secretin stimulation test does not cause a rise in plasma insulin due to the unresponsiveness of insulinoma cells to secretin. (Imamura, M., et al. 1990)

\subsubsection{C-peptide inhibition test with hog insulin}

After proinsulin cleavage, insulin and c-peptide are secreted. Infusion of hog insulin for 1 hour leads to the decrease of plasma c-peptide levels in healthy subjects, but no such decrease is observed in insulinoma patients. Insulin release from insulinoma cells is not inhibited by the administration of exogenous insulin, whereas insulin secretion from normal beta-cells is inhibited by the increased plasma insulin. (Service, FJ., et al. 1992)

\subsection{Diagnostic imaging}

The diagnostic suspicion of an insulinoma is based on symptoms, and laboratory techniques usually confirm the diagnosis. The treatment, on the other hand, is usually surgery of the tumoral mass as complete as possible, including the primary tumor and metastases if present. Imaging of the primary tumor location and the extent of the disease is needed for all phases of management of pancreatic neuroendocrine tumors. It is needed to determine whether the surgical resection for possible cure or possible cytoreductive surgery is needed and whether treatment for advanced metastatic disease is appropriate and during follow-up to assess the effects of any antitumor treatment as well as the need for deciding whether additional treatments are indicated. Imaging plays also a pivotal role in differentiating these tumors from adenocarcinomas of the pancreas. As a result, a fundamental part in the process of the diagnosis and treatment of an insulinoma will be the localization with imaging techniques.

Insulinomas are often of a small size and localization may be difficult. A number of different imaging modalities have been widely used including conventional imaging studies (CT, MRI, ultrasound, angiography), endoscopic ultrasound, functional localization studies measuring hormonal gradients, intraoperative methods particularly intraoperative ultrasound and recently PET preoperatively.

\subsubsection{Abdominal ultrasound}

Abdominal ultrasound has the advantages of being a non-invasive technique, free of radiation, anatomically precise, low-cost and world-wide used. On the other hand, key major drawbacks include its dependence on the operator expertise and on the limitations based on the patient's habitus that is usually unfavorable since many insulinoma patients are overweight or obese.

Regular ultrasound investigation of the pancreas is rarely helpful in the localization of an insulinoma. The sensibility reported with this technique to detect insulinoma is low, about $9 \%$. However, it is done routinely to exclude the presence of liver metastases before surgery. Commonly, it is the first imaging technique to detect liver metastases and therefore leading to the performance of more precise techniques which detect the malign insulinoma.

\subsubsection{Endoscopic ultrasonography (EUS) of the pancreas}

EUS is a relatively new technique. It is remarkably accurate locating pancreatic neuroendocrine tumors, especially those located in the pancreatic tail (Figure 5). EUS requires the availability of expensive echoendosonographic and processing equipment. Such equipment is found only in large hospitals or endoscopy units.

Most gastroenterologists now consider EUS to be the most accurate, least expensive preoperative method of locating neuroendocrine pancreatic tumors. The technical 
advantage of EUS imaging over transabdominal ultrasonography is due to the close proximity of the transducer to the target. This permits the use of high scanning frequencies, which provide much greater spatial resolution. Rosch et al. prospectively compared the accuracy of EUS and ultrasonography, computed tomography, and endoscopic retrograde cholangiopancreatography in the detection of pancreatic tumors.22 The sensitivity and specificity of EUS in localizing pancreatic tumors is 99 and $100 \%$, respectively, compared with ultrasonography (67 and 40\%, respectively) and computed tomography (77 and 53\%, respectively) and is equal to endoscopic retrograde cholangiopancreatography (sensitivity of $90 \%)$.

In a recent multicenter study, EUS was shown to be the most sensitive localization modality in accurate detection of pancreatic tumors (sensitivity of 82 versus $27 \%$ ) and had a specificity of $95 \%$. EUS accurately defines the size of tumors to within $2 \mathrm{~mm}$ of the excised lesion.

EUS is a valuable method of localizing insulinomas. The technique requires specialized endoscopic skill, but it is both safe and effective in experienced hands. EUS should prove to be very helpful for localization of insulinomas undetectable by transabdominal ultrasonography or computed tomography, but it is not a satisfactory method for evaluating the liver in patients suspected to have metastatic disease. (Andersen, A., et al, 2004)

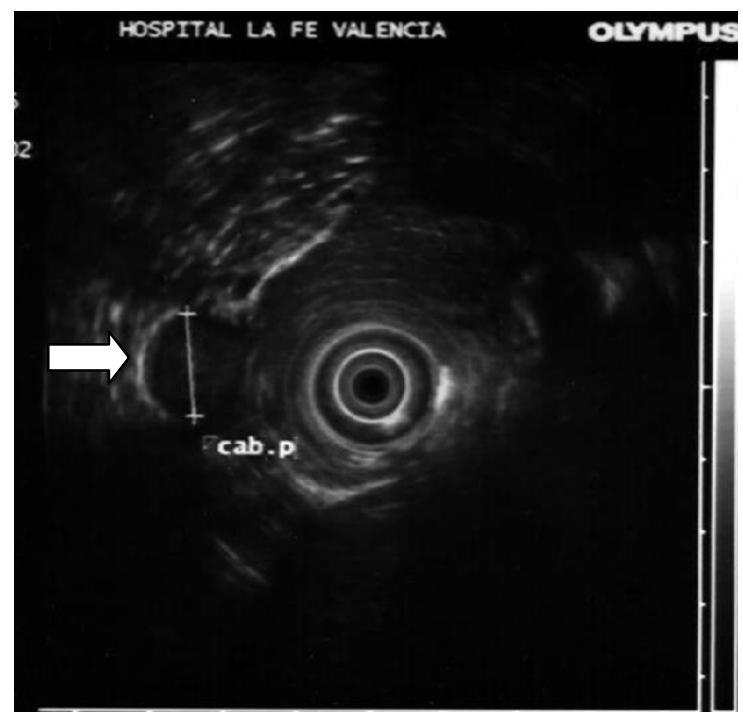

Fig. 5. Endoscopic ultrasonography of a bening insulinoma. The arrow points the tumoral mass.

\subsubsection{Computed tomography (CT)}

Although in recent years gadolinium-enhanced MR imaging, somatostatin-receptor imaging, and endosonography have emerged as potentially competing or complementary techniques to $\mathrm{CT}$, dual-phase helical CT, particularly with technical improvements afforded by multidetector $\mathrm{CT}$, remains the dominant imaging modality for the diagnosis of all pancreatic neoplasms, including islet cell tumors. In expert hands, helical CT can detect about two-thirds of the insulinomas. 
Because of their rich vascular supply, insulinomas classically are hyperattenuating compared with the surrounding pancreatic parenchyma on contrast-enhanced CT. Capturing the vascular blush is essential for the diagnosis of small tumors, which often do not distort the contour of the pancreas. This is particularly true in the investigation of functioning insulinomas because these are often small, with $50 \%$ measuring less than $1.3 \mathrm{~cm}$. The classic and most common enhancement pattern of islet cell tumors is that of a hyperattenuating lesion in the arterial and venous phases. Many small lesions enhance more prominently and thus are easier to detect in the arterial phase or become inconspicuous in the venous phase. In a series of 11 cases of functioning islet cell tumors reported by Van Hoe et al., most lesions were hyperattenuating and two were more conspicuous on arterial phase imaging. Helical CT is not only useful for the detection of the insulinoma but also in the staging of malignant insulinoma on dual-phase CT. Three-dimensional CT reconstructions exquisitely show local extension and encasement of the major peripancreatic arteries and veins for surgical planning. The liver and regional lymph nodes are the most common sites for metastases. Like the primary tumor, liver metastases are hypervascular. Arterial phase images show the number and size of the hepatic lesions better than images acquired in the venous phase, particularly for small metastases. Spread to regional lymph nodes also is more conspicuous in the arterial phase.

The reported sensitivity of CT in localizing functioning islet cell tumors varies from $71 \%$ to $82 \%$ because small tumors are more frequently missed. Small hyperattenuating islet cell tumors located in the pancreatic neck or body can be confused with adjacent vascular structures; multiplanar reconstruction is helpful in separating the lesion from surrounding vessels, thus improving diagnostic confidence. (Sheth, S., et al, 2002).

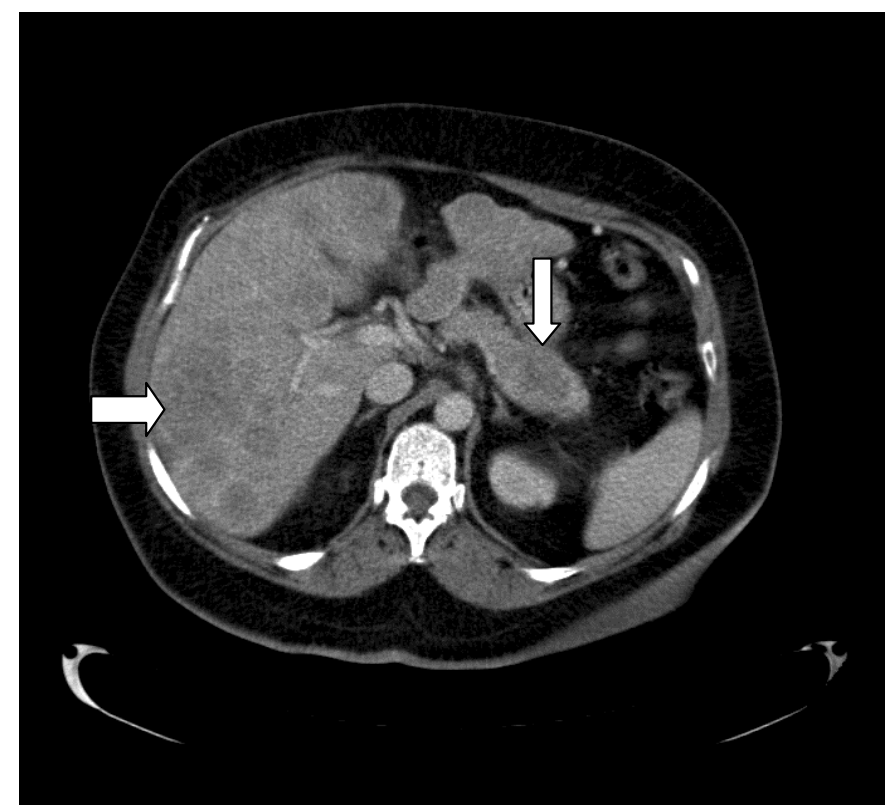

Fig. 6. CT scan of malignant insulinoma (no contrast). Hypointense solid irregular mass of 2 $x 3 \mathrm{~cm}$ in the tail of the pancreatic gland. Hepatomegaly with multiple metastases, solid and hypointense, of different sizes, the bigger one of $5.5 \mathrm{~cm}$. 


\subsubsection{Magnetic resonance imaging}

Recent reports have suggested an important role for MRI in the detection of pancreatic NET, in particular with the use of fast spin echo and fat saturation techniques. MRI has presented excellent results, its sensitivity ranges from $85-95 \%$ in the detection of insulinomas (including those with less than $1.5 \mathrm{~cm}$ in diameter) and the determination of the presence of metastases.

Using conventional sequences, small insulinomas usually have a low signal on T1-weighted sequences and a high signal on T2-weighted sequences. Some insulinomas containing fibrous tissue may show low signal intensity on both T1 and T2 weighted images.

An improvement in MRI techniques is the use of diffusion weighted MRI. Fat suppressed $\mathrm{T}_{1}$ weighted sequences have been reported to be particularly useful in imaging pancreatic lesions, especially islet cell tumours. The normal pancreas is of relatively high signal intensity on fat saturated $\mathrm{T}_{1}$ weighted images. Islet cell tumors are of lower signal intensity than normal pancreatic tissue. This increased contrast between tumors and pancreas explains the greater detection rate with fat suppressed $\mathrm{T}_{1}$ weighted images. (Semelka, RC., et al, 2000)

\subsubsection{Angiography and arterial stimulation of the pancreas}

Although most insulinomas are small, they have been successfully detected by computed tomography and magnetic resonance imaging recently. However, preoperative localization of the insulinomas by arterial stimulation with venous sampling is crucial when they show atypical findings on these imaging modalities.

That is, it is difficult to determine whether the tumor is benign or malignant, whether it is a nonfunctioning tumor accompanying an extra or undetectable pancreatic insulinoma, or whether it is one of the multiple insulinomas. Morphological imaging modalities do not reflect hormonal functions; however, the addition of angiography and arterial stimulation helps regionalize a tumor by verifying the hormonal function. This procedure enhances a more accurate surgical approach in clinical exploration and can prevent a possible resurgery. Thus, for atypical insulinomas, preoperative localization of insulinomas by angiography and arterial stimulation may be particularly important.

Mesenteric angiography is a well established invasive technique in which pancreatic endocrine tumors appear as a well circumscribed blush, usually four to eight seconds after the contrast injection. The reported sensitivity for the detection of primary tumors ranges between 28 and 70 percent. The accuracy for diagnosing hepatic metastases is higher (sensitivity 62 to 78 percent).

Arterial stimulation venous sampling involves selective injections into arteries supplying the pancreas of a stimulating secretagogue. Insulin production is measured in the pancreatic gland by a catheterization of the main arteries (superior mesenteric artery, gastroduodenal artery, hepatic artery and splenic artery). Insulin secretion is stimulated by an injection in each of these arteries of calcium $(0.025 \mathrm{mEq} / \mathrm{kg})$ diluted in a $5 \mathrm{~mL}$ injection. Plasma extractions are done at $0,30,60,90$ and 120 seconds after the injection. The test is considered positive if there is an increase of insulin two-fold greater the basal between 30 and 120 seconds. This technique permits de location of the tumor in the portion of the pancreas which is irrigated by one of these arteries.

Results with this technique are encouraging. One report evaluated 24 patients with proven hyperinsulinemia. Seven of these patients had negative imaging technique and in all of them calcium infusion permitted localization of the source of insulin secretion. Although helpful, angiography and arterial stimulation is an invasive and costly technique that should be reserved for atypical insulinomas or when nesidioblastosis is suspected. 


\subsubsection{Scintigraphy with octeotride}

The absence of somatostatin receptors in half of insulinomas and the lack of spatial discrimination with nuclear scanning are detractions to the routine use of this new localization test.

In addition, scintigraphic imaging with Octreoscan has been introduced in an attempt to improve topographic assessment of insulinomas. The results were disappointing, since Octreoscan scintigraphy with planar imaging led to detection of only $20-50 \%$ of insulinomas

\subsubsection{Positron emission tomography PET}

The results of 18-fluordeoxyglucose (18-FDG) PET imaging for insulinomas are not very promising, maybe due to the low proliferative potential of these tumor cells. Positive results have been shown using 11 C-5-hydroxi-L-tryptophan, 18-3, 4-Dihydroxy-6-fluoro-DLphenylalanine and 67-Ga-DOTA-DPhe 1-Tyr 3-octeotride due to selective uptake in tumor tissue compared to surrounding tissue. These techniques produce very good tumor visibility and can be used for the examination of both the thorax and abdomen. However, the lack of general availability of PET scanning and high cost, limits its use.

\subsubsection{PET/TC}

The 18-fluorine-18-fluoro-2-deoxyglucose Positron Emission Tomography coupled with computed tomography is a non invasive exploration. Several studies have shown that PETCT has superior efficacy over conventional imaging techniques in distinguishing a benign pancreatic tumor from a malignant one. It contributes to the diagnosis of cancer in patients with a doubtful mass, much more in case of chronic pancreatitis.

\subsubsection{Intraoperative localization techniques}

Intraoperative ultrasonography allows high resolution examination of the pancreas. When combined with palpation of the organ, the sensitivity for tumor detection ranges 83 to 100 percent. Intraoperative transillumination has equivalent efficacy (sensitivity of 83 percent). Neither of these tests should replace preoperative imaging; they are used as adjuncts to intraoperative palpation. (Figure 7)

\section{Diagnostic algorithm for insulinomas}

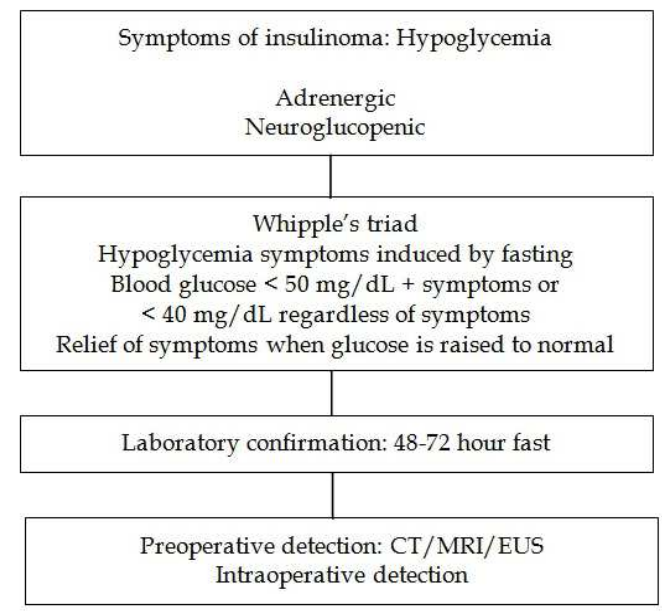




\section{Staging of insulinoma tumors}

After the performance of imaging techniques, insulinomas which are the most frequent neuroendocrine pancreatic tumors, must be classified. The classification proposed by AJCC (American Joint Committee on Cancer) ENETS (European Neuroendocrine Tumor Society) for neuroendocrine pancreatic tumors is the following (Table 4):

\begin{tabular}{|c|c|}
\hline$\underline{\mathbf{A J C C}}$ & $\underline{\text { ENETS }}$ \\
\hline Primary Tumor $(T)$ & Primary Tumor $(\mathrm{T})$ \\
\hline $\begin{array}{l}\text { TX Primary tumor cannot be assessed } \\
\text { T0 No evidence of primary tumor } \\
\text { T1 Tumor limited to the pancreas, }<2 \mathrm{~cm} \text { in } \\
\text { greatest dimension } \\
\text { T2 Tumor limited to the pancreas, }>2 \mathrm{~cm} \text { in } \\
\text { greatest dimension } \\
\text { T3 Tumor extends beyond the pancreas but } \\
\text { without involvement of the celiac } \\
\text { axis or the superior mesenteric artery } \\
\text { T4 Tumor involves the celiac axis or the } \\
\text { superior mesenteric artery } \\
\text { (unresectable primary tumor) }\end{array}$ & $\begin{array}{l}\text { TX Primary tumor cannot be assessed } \\
\text { T0 No evidence of primary tumor } \\
\text { T1 Tumor limited to the pancreas and size }<2 \mathrm{~cm} \\
\text { T2 Tumor limited to the pancreas and size } \\
2-4 \mathrm{~cm} \\
\text { T3 Tumor limited to the pancreas and size } \\
>4 \mathrm{~cm} \text { or invading duodenum or bile } \\
\text { duct } \\
\text { T4 Tumor invading adjacent organs (stomach, } \\
\text { spleen, colon, adrenal gland) or the } \\
\text { wall of large vessels (celiac axis or } \\
\text { superior mesenteric artery) }\end{array}$ \\
\hline Regional lymph nodes (N) & Regional lymph nodes (N) \\
\hline $\begin{array}{l}\text { NX Regional lymph node(s) cannot } \\
\text { be assessed } \\
\text { N0 No regional lymph node metastasis } \\
\text { N1 Regional lymph node metastasis }\end{array}$ & $\begin{array}{l}\text { NX Regional lymph nodes cannot } \\
\text { be assessed } \\
\text { N0 No regional lymph node metastasis } \\
\text { N1 Regional lymph node metastasis }\end{array}$ \\
\hline Distant metastases (M) & Distant metastases (M) \\
\hline $\begin{array}{l}\text { M0 No distant metastasis } \\
\text { M1 Distant metastasis }\end{array}$ & $\begin{array}{l}\text { MX Distant metastasis cannot be assessed } \\
\text { M0 No distant metastasis } \\
\text { M1 Distant metastasis }\end{array}$ \\
\hline Endocrine and Exocrine pancreas & Endocrine and Exocrine pancreas \\
\hline Stage T N M & Stage T N M \\
\hline 0 T0 NO M0 & \\
\hline $\begin{array}{l}\text { IA T1 N0 M0 } \\
\text { IB T2 N0 M0 }\end{array}$ & I T1 N0 M0 \\
\hline IIA T3 N0 M0 & IIa T2 N0 M0 \\
\hline $\begin{array}{l}\text { IIB T1 N1 M0 } \\
\text { T2 N1 M0 } \\
\text { T3 N1 M0 }\end{array}$ & IIb T3 N0 M0 \\
\hline III T4 Any N M0 & $\begin{array}{l}\text { IIIa T4 N0 M0 } \\
\text { IIIb Any T N1 M0 }\end{array}$ \\
\hline IV Any T Any N M1 & IV Any T Any N M1 \\
\hline
\end{tabular}

Table 4. Staging of TNEs of the pancreas according to AJCC and ENETs 
The WHO has an alternative classification and staging for pancreatic neuroendocrine tumors, which considers also certain anatomopathological findings. The proliferative rate has been repeatedly shown to provide significant prognostic infromation for NETs. The proliferatice rate can be assessed as the number of mitosis per unit area of tumor (usually expressed as mitosis per 10 high power microscopic fields or $2 \mathrm{~mm}$ ) or as the percentage of neoplastic cells immunolabeling for the proliferation marker Ki-67. The use between mitotic count and Ki-67 is controversial. When the amount of tumor tissue is limited, it may not be able to perform an accurate mitotic count. In these cases Ki 67 staining provides a more accurate assessment of proliferative rate, and it is particularly helpful to separate welldifferentiated tumors from poorly differentiated neuroendocrine carcinomas, which usually have dramatically different Ki 67 labelling rates. However, when adequate tissue is present to perform an accurate mitotic count, there are no data to demonstrate that the Ki67 labeling index adds important information, and in some cases, the two measures of proliferative rate may provide conflicting information about grading.(Table 5)

\begin{tabular}{|c|c|c|c|c|c|c|c|}
\hline $\begin{array}{c}\text { Grade } \\
\text { (WHO) }\end{array}$ & $\begin{array}{c}\text { Biological } \\
\text { behavior }\end{array}$ & M1 & Histology & $\begin{array}{c}\text { Angio } \\
\text { invasion }\end{array}$ & $\begin{array}{c}\text { Primary } \\
\text { tumor } \\
\mathbf{( c m})\end{array}$ & $\begin{array}{c}\text { Ki- } \\
\mathbf{6 7} \%\end{array}$ & $\begin{array}{c}\text { Mitotic } \\
\text { count }\end{array}$ \\
\hline 1 & Benign & - & $\begin{array}{c}\text { Good } \\
\text { differentiation }\end{array}$ & - & $<2$ & $<2$ & $<2$ \\
\hline 1 & Undefined & - & $\begin{array}{c}\text { Good } \\
\text { differentiation }\end{array}$ & $+/-$ & $>2$ & $2-5$ & $<2$ \\
\hline 2 & $\begin{array}{c}\text { Malignancy } \\
\text { low grade }\end{array}$ & + & $\begin{array}{c}\text { Good } \\
\text { differentiation }\end{array}$ & + & $>3$ & $5-15$ & $2-10$ \\
\hline 3 & $\begin{array}{c}\text { Malignancy } \\
\text { high grade }\end{array}$ & + & $\begin{array}{c}\text { Poor } \\
\text { differentiation }\end{array}$ & + & whatever & $>15$ & $>10$ \\
\hline
\end{tabular}

Table 5. WHO staging for pancreatic neuroendocrine tumors

\section{Medical management of insulinoma related to hormone hypersecretion}

Benign insulinomas, as well as malignant, usually produce high concentrations of insulin secretion developing the well-known hypoglycemic syndrome. Independently of their surgical possibilities, hypoglycemia must be controlled.

With insulinomas, dietary modification with frequent small feedings may help control hypoglycemia. Sometimes endovenous glucose infusion may be needed to maintain acceptable glucose levels usually in the preopreatory or when it is a high secreting malignant insulinoma. Glucose infusion must be done with care as patients may develop in rare cases acidosis secondary to large volumes of glucose infusion (Ramos,A., et al., 2010). When diet modification does not control the symptoms, pharmacological treatment must be used. There are several pharmacological treatments the most frequently used is diazoxide followed by somatostatin analogues. (Hirshberg, B., et al 2005)

\subsection{Diazoxide}

Administration of diazoxide (200-600 mg/day) successfully controls hypoglycemia in 50 to $60 \%$ of the patients. The most common side effect reported with diazoxide is hirsutism as well as nausea at higher dose administration. Also, diazoxide frequently leads to fluid 
retention requiring diuretics such as triclormetiazide which not only counteracts this sideeffect but has also a hyperglycemic effect.

Diazoxide enables the control of the hypoglycemia by two mechanisms: it inhibits insulin secretion by beta-cell pancreatic cells and it has a peripheral effect stimulating glucogenolisis. Treatment with diazoxide has proven to be efficient, including cases with nesidioblastosis in which surgery seemed to be a very radical option. In advanced metastatic disease in which surgery is not an option, diazoxide has demonstrated in some studies to be more effective in the symptomatic control at short-time.

\subsection{Calcium antagonists and others}

Calcium antagonists may also be useful controlling hypoglycemia because they inhibit insulin secretion by the blockage of the calcium receptor. There are some works on advanced metastatic disease that describe a better symptomatic control with verapamil added to the long-acting somatostatin analogues. On the other hand, the data of their use is limited, therefore limiting their use to cases with advanced disease in which other treatments are uneffective.

Other options to control hypoglycemia may be beta blockers, that can be useful, although they might be used with precaution as they can mask hypoglycemia symptoms. Other pharmacological treatments include phenytoin or glucagon. Glucocorticoids increase gluconeogenesis and create insulin resistance, so they can also be useful. The recommended dose is of $1 \mathrm{mg} / \mathrm{kg}$ of prednisone.

\subsection{Somatostatin analogues}

Long-acting somatostatin analogues have proved to be a novel and very useful treatment in the control of hypoglycemia.

Lately the presence of somatostatin in pancreas islets and other areas of the digestive tract, as well as its inhibitory effect of the secretion of other hormones, such as insulin, its role as neurotransmisor or neuromodulator and cytostatic effect have been recognized. Somatostatin was therefore considered as a possible treatment for those endocrinological syndromes caused by excess hormone production. However, human somatostatin has a very short half-life effect, which made the development of what today we know as the longacting somatostatin analogues.

Their main indication is in the preoperatory phase, or in cases of recurrence and malignancy. Also, although it is not their main indication, cases of complete resolution in benign insulinomas have been reported. These analogues function predominantly over subtype 2 somatostatin receptor and less over subtype 5, controlling therefore about $50 \%$ of the hypoglycemic events caused by insulinomas. The somatostatin subtype 5 receptor has been involved in insulin secretion and seems to be related with a more aggressive tumoral behavior. New somatostatin analogues are being developed with a greater affinity to this and other receptors such as BIM23244 and SOM230.An important aspect before starting the treatment of an insulinoma with somatostatin analogues is to analyze the possible efficacy by the performance of an Octreoscan or by demonstrating an improvement on glucose and insulin levels with short-acting somatostatin analogues. This is important because their use in tumors which do not express subtype 2 may worse the hypoglycemia by the inhibition of the contrarregulatory response of glucagon and growth hormone without affecting insulin secretion. Another possible problem when long-acting somatostatin analogues are used long- 
term, is a desensibilization of the tumor by a decrease in the expression of the somatostatinreceptors. Initially this can be overwhelmed by increasing the dose of the analogue or decreasing the interval administration, but can cause at the end a therapeutic fail.

\subsection{New agents to control hypoglycemia}

Recent studies in small numbers of patients show that mTOR inhibitors, such as rapamycin or everolimus, may control hypoglycemia in patients with metastasic insulinomas.

Everolimus is an orally derivative of rapamycin that inhibits Ser/Thyrosine kinase mTOR. The PI3k/Akt/mTOR pathway has an important role in pancreatic cancer biology. It has demonstrated to have an antitumor activity, but its effects on pancreatic beta cells remains unclear. Data suggest that functional insulin receptors are present on beta cells and mediate insulin stimulated insulin production and release and that mTOR inhibition downstream of insulin receptors may decrease insulin production and release. It is also possible that everolimus induces insulin resistance peripherically.

Recent case series have reported malignant insulinomas with severe hypoglycemic syndrome who were able to cease, or significantly reduce symptoms after the introduction of everolimus.

\begin{tabular}{|c|c|c|c|}
\hline $\begin{array}{c}\text { MEDICAL THERAPY FOR } \\
\text { UNCONTROLLED HYPOGLYCEMIA }\end{array}$ & \multicolumn{2}{|l|}{} \\
\hline DRUG & CLASS & $\begin{array}{c}\text { SYMPTOM } \\
\text { CONTROL }\end{array}$ & ADVERSE EFFECTS \\
\hline Diazoxide & $\begin{array}{c}\text { Alpha adrenergic } \\
\text { agonist }\end{array}$ & $\begin{array}{c}50-60 \% \text { of patients } \\
\text { peripheral edema, } \\
\text { nausea, hirsutism }\end{array}$ \\
\hline Verapamil & Comatostatin analog & blo-60\% of patients & $\begin{array}{c}\text { bloating, abdominal } \\
\text { cramping, } \\
\text { malabsorption, } \\
\text { cholelithiasis }\end{array}$ \\
\hline Propranolol & Beta-blocker & unknown & $\begin{array}{c}\text { bradycardia, depression, } \\
\text { may potentiate } \\
\text { hypoglycemia }\end{array}$ \\
\hline Phenytoin & Anticonvulsivant & unknown & $\begin{array}{c}\text { hypertrichosis, gingival, } \\
\text { hypertrophy, peripheral } \\
\text { neuropathy }\end{array}$ \\
\hline Prednisone & Glucocorticoids & unknown & Cushingsyndrome \\
\hline Glucagon & Glucagon & palliation & $\begin{array}{c}\text { risk of rebound } \\
\text { hypoglycemia }\end{array}$ \\
\hline
\end{tabular}

Table 6. Medical Therapy for Uncontrolled hypoglycemia

\section{Surgical treatment of benign insulinoma or primary tumor}

All experts agree that surgical resection of an insulinoma either benign or malignant should be considered whenever possible. Local resection or enucleation of the insulinoma is generally recommended, and more advanced surgical resections such as Whipple resections 
are not routinely recommended and should be considered only in carefully selected patients. (Figure 7 and 8 )

Generally pancreatic neuroendocrine tumors are surgically approached by a laparotomy to allow an extensive exploration of the entire abdomen and search for lymph node metastases. Insulinomas in non-MEN 1 with benign characteristics are increasingly being treated with a laparoscopic approach; in $85 \%$ of patients, there are single tumors, they are invariably intrapancreatic, and if they can be localized preoperatively, they can be cured in $70 \%$ to $100 \%$ using laparoscopic approach. At the present surgical cure rates for benign insulinomas approach $100 \%$.
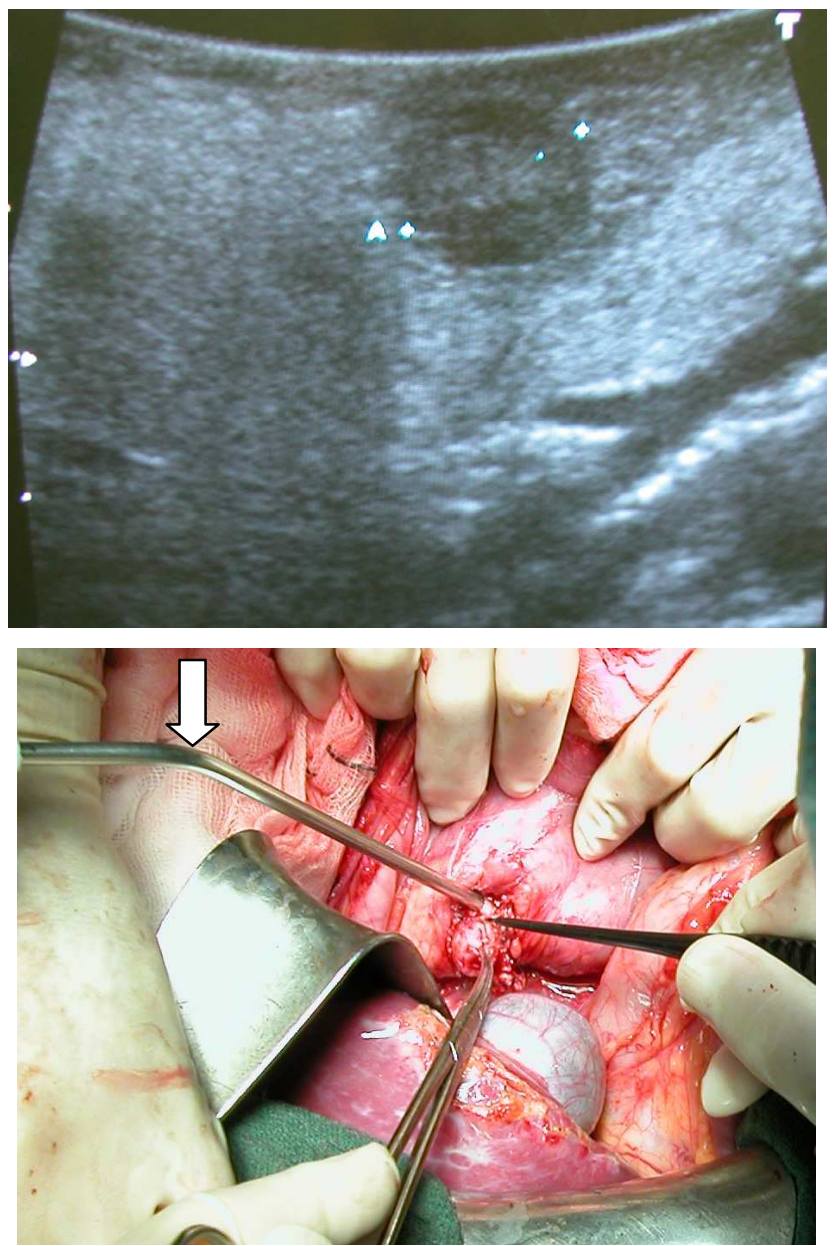

Fig. 7. Bening insulinoma. .Upper image:. Intraoperatory ultrasonography. .Lower image:. Enucleation of the same tumoral mass.

When clinical examinations including angiography stimulation suggest nesidioblastosis, a partial pancreatectomy is usually performed. Even if a frozen biopsy confirms the diagnosis 
of nesidioblastosis, the extent of pancreatic resection remains questionable. A distal pancreatectomy which can control the symptoms of the majority of patients, is well tolerated, and does not induce endocrine or exocrine insufficiency. Recovery after a partial pancreatectomy can remove enough abnormal proliferative tissue to achieve normoglycemia. However, some investigators recommend an initial near-total pancreatectomy. Such extensive resections lead to an increased risk of post-surgical diabetes and pancreatic insufficiency. It seems that the best recommendation is a $70 \%-80 \%$ pancreatectomy, administration of diazoxide when hypoglycemia persists post-operatively, and a more extensive resection when previous measures fail.

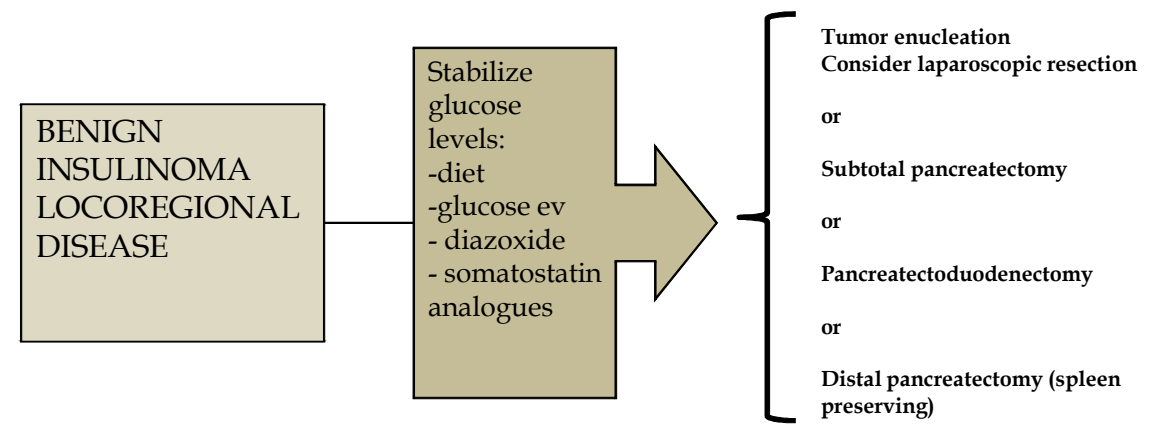

Fig. 8. Therapeutical algorithm for benign insulinoma or primary located disease

\section{Additional management in advanced insulinomas}

Malignant insulinomas, although unfrequent, may require multiple managements involving a mutidisciplinar follow-up. Firstly hypoglycemic syndrome must be adequately controlled. Secondly, surgical approach must be used if possible, to control metastasic and primary disease. When curative surgery is not possible, usually due to metastasic disease, debulking surgery is often a beneficial treatment for local (intestinal obstructions, etc.) and endocrine symptoms. On the other hand, when the disease is extended and surgical approach is not possible, other therapeutic options can be used depending on the organ affected.(Figure 9 and 10).

\subsection{Surgical approach of metastasic disease}

Hepatic resection is indicated for the treatment of metastasic liver disease in the absence of diffuse bilobar involvement, compromised liver function or extensive extrahepatic metastases.

However, the role of cytoreductive surgery in these cases is controversial. Whereas numerous uncontrolled studies provide evidence that surgical resection may improve symptom control and perhaps extend survival, neither result is proven at the present. Nevertheless, because of the low efficacies of other tumor treatments, most conclude that surgical resection should be attempted in any patient with a malignant insulinoma if it is thought that at least $90 \%$ of the visible tumor could be removed. Unfortunately, surgical resection of at least $90 \%$ of all visible tumor is possible only in $5 \%$ to $15 \%$ of patients with insulinoma and metastasic disease. 

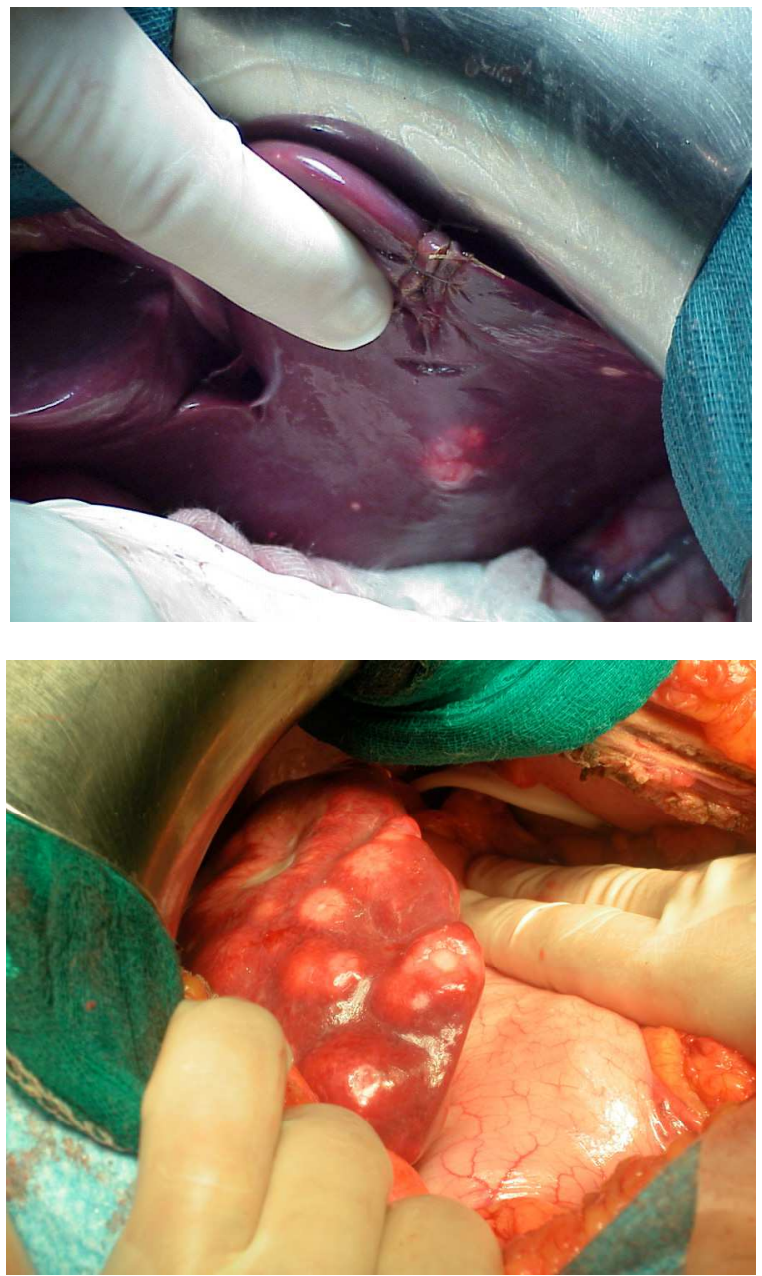

Fig. 9. Metastasic disease of insulinoma.Upper image: single hepatic metastases. Lower image: multiple hepatic metastases.

Transplantation for metastasic disease has been proposed for the occasional, younger patient with a metastasic insulinoma that is unresectable and limited to the liver, especially if it is symptomatic and cannot be controlled by other available therapies, that liver transplantation remains an option that should be considered.

\subsection{Other invasive therapies}

Hepatic artery embolization is recommended as a palliative option in patients with hepatic metastases who are not candidates for surgical resection, have an otherwise preserved performance status, have disease primarily confined to the liver, and have a patent portal vein. The response rates associated with embolizations, as measured either by decrease in hormonal secretion or by radiographic regression are generally greater than $50 \%$. Improved 
techniques have, in recent years, reduced the incidence complications related to embolization, making embolization an important and generally safe treatment. A number of techniques can be used and include bland embolization, chemoembolization, embolization with chemotherapy and embolization using radioisotopes. These techniques should be considered especially for a patient with a functional secreting insulinoma in which the hormone excess cannot be controlled by other methods. (O'Toole, D., et al 2005)

Other approaches to the treatment of hepatic metastases in a patient with malignant insulinoma include the use of radiofrequency and crioablation, either alone or in conjuction with cytoreductive surgery. These approaches can be performed using a percutaneous or laparoscopic approach. Although they seem to be less morbid than either hepatic resection or hepatic artery embolization, the clinical benefit of these approaches in patients with asymptomatic, small volume disease has not been clearly established. Similarly, these approaches may not be applicable in patients with large-volume hepatic metastases. Ablative techniques should therefore be considered as a treatment option only in carefully selected patients. (Steinmuller, T., et al 2008)

Peptide receptor radionuclide therapy can be an option in those pancreatic tumors which have an overexpression of somatostatin receptors. This expression is not frequent within insulinomas.

\subsection{Radiotherapy}

Experience with external beam radiotherapy in the management if islet tumor cells is limited. Although pancreatic neuroendocrine carcinomas were previously considered to be radioresistant, data from published case reports and small case series suggest that radiotherapy can produce high rates of symptom palliation and freedom from local progression in patients who are not candidates for surgical resection. There are no specifical data on the rate of symptom control in patients with symptomatic insulinomas.

However, radiotherapy with or without biphosphonates has proven to be highly useful in patients with painful bony metastases.

\subsection{Traditional chemotherapeutic agents}

A number of chemotherapeutic agents either alone or in combination have been reported to have sufficient antitumor activity to be clinically useful. Systemic chemotherapy is recommended for patients with unresectable liver or lung metastases. Trials using chemotherapeutic drugs including doxorubicin, streptoxocin, 5-FU, temozolamide, and dacarbazine have established cytotoxic effects in pancreatic tumors. The combination of doxorubicin and streptozocin has a reported $69 \%$ objective response rate in the treatment of patients with advances islet cell carcinoma. A retrospective review from the MD Anderson Center reported an objective response rate of $39 \%$ with the combination of 5FU, doxorubicin and streptozocin. Fine et al have reported on the synergy between capecitabine and temozolamide for the induction of apoptosis in neuroendocrine cell lines. Recently, an oral regimen using temozolamide and thalidomide was found to be useful in a number of neuroendocrine malignancies. (Kouvaraki, M., et al. 2004)

\subsection{Newer agents}

\subsubsection{Biotherapy: Somatostatin analogues and interferon}

Somatostatin analogues have a double purpose in the treatment of insulinomas, firstly they can control hypoglycemia and secondly they are used in those patients with advanced 
disease for their possible effect on tumor growth. The clinical benefit of the direct antineoplasic effects of somatostatin analogues either with or without interferon remains uncertain, although recent studies suggest they have a cytostatic effect in 40 to $70 \%$ of patients and cause a tumor reduction of less than $15 \%$ with both agents. This tumoristatic effect can be long lasting especially in those with low proliferative rate. (Plockinger, U., et al. 2007)

\subsubsection{Anti-angiogenic treatments}

Recent studies using vascular endothelial growth factor (VEGF) pathway inhibitors such as bevacizumab have suggested that these agents may have a modest antitumor activity in patients with malignant pancreatic tumors. Actually there are several active studies combining chemotherapy and bevacizumab in adavanced pancreatic NETs. However the recruited patients are small, and for the moment there are no specifical results for malignant insulinomas.

Sunitinib inhibits celular signaling by targeting multiple receptor tyrosine kinases. These include all receptors for platelet-derived growth factor (PDGF-Rs) and VEGF receptors, which play a role in both tumor angiogenesis and tumor cell proliferation. The simultaneous inhibition of these targets therefore leads to both reduced tumor vascularization and cancer cell death, and ultimately tumor shrinkage. In phase 1 and 2 trials, sunitinib showed antitumor activity in patients with pancreatic neuroendocrine tumors. A phase 3 has been recently conducted in well-differentiated pancretic neuroendocrine tumors in which the results were promising causing a discontinuation of the study. Median progression-free survival was 11.4 months in the sunitinib group as compared with 5.5 months in the placebo group (hazard ratio for progression or death, $0.42 ; 95 \%$ confidence interval $[\mathrm{CI}], 0.26$ to $0.66 ; \mathrm{P}<0.001$ ). There are no results for the moment specifical in malignant insulinomas. (Raymond, E., et al 2011)

\subsubsection{Inhibiton of $\mathrm{m}$-TOR}

Everolimus, an inhibitor of mTOR has also being study recently not only from the antihipoglycemic but also from the antitumoral point of view. Its efficacy has been studied combined with somatostatin analogues in neuroendocrine tumors. Considering insulinomas, the mean survival without progression was estimated in 63 weeks. (Yao et al., 2008). Considering other studies with pancreatic NETs in general, everolimus (at a dose of $10 \mathrm{mg} /$ day) caused a 65\% reduction in the estimated risk of progression (progression-free survival of 11 months with everolimus versus 4.6 months with placebo, $\mathrm{p}<0.001$ ). Confirmatory studies of these promising results are being performed.

\section{Posttreatment surveillance}

After the complete removal of the tumor, a patient with a benign insulinoma is cured, but periodic follow-up is necessary in those with metastasic insulinoma or multiple endocrine neoplasia type 1 (MEN1).

\subsection{MEN 1}

All patients with MEN 1 syndrome should be followed with every 3-6 months during the first year after resection with physical examination, tumoral markers and calcium levels as appropriate and with imaging studies such as CT/MRI. The follow-up tests must be repeated every 6 months, 1-3 years after surgery and annually thereafter.

All close family members of patients with MEN 1 should be genetically counseled and genetic testing should be considered. 


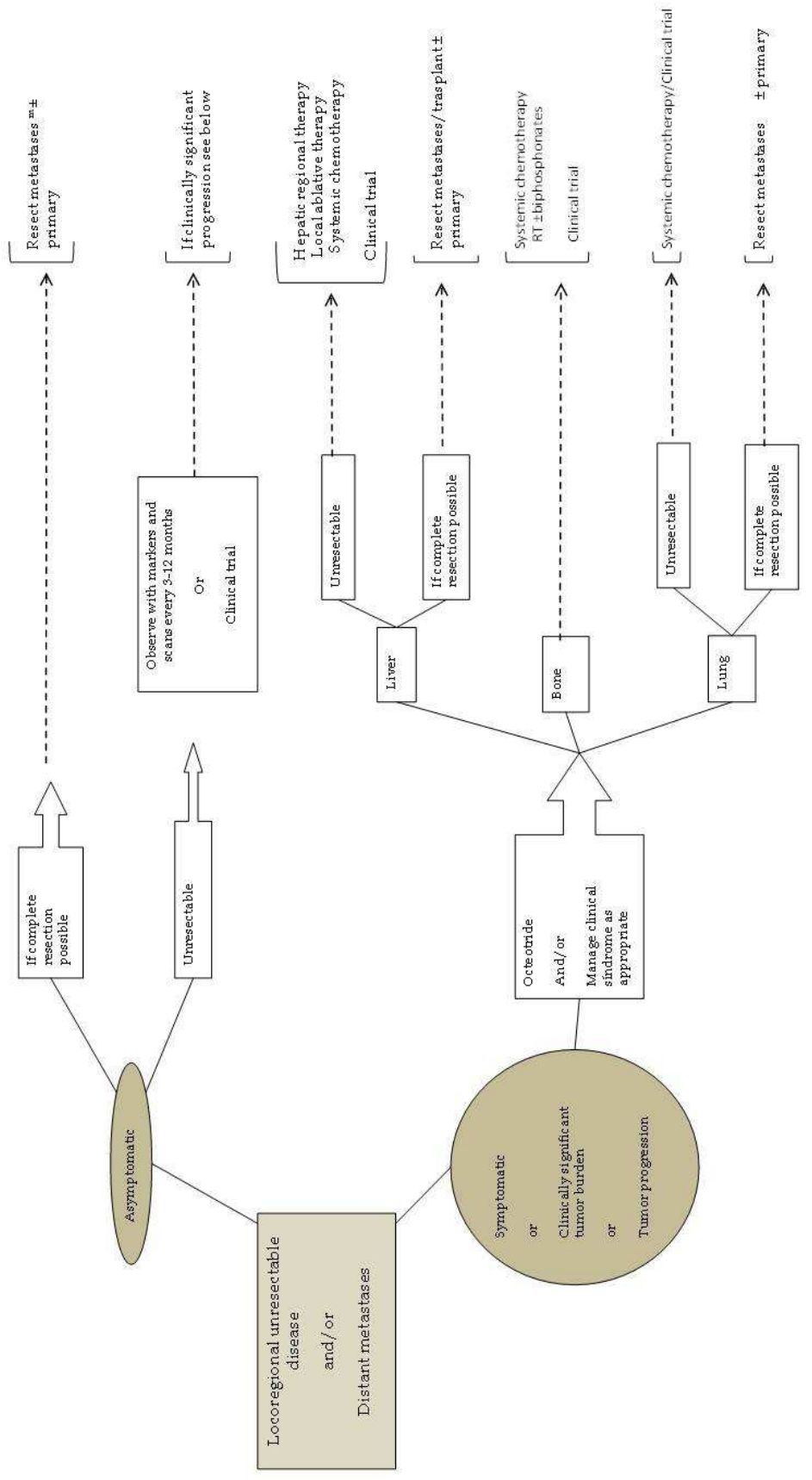

Fig. 10. Therapeutic algorithm of malignant insulinoma. Adapted from National Comprehensive Cancer Network, 2010. 


\subsection{Malignant insulinoma}

There are no evidence-based guidelines for follow-up after resection of a malignant insulinoma. Consensus derived guidelines from the National Cancer Network following treatment of an islet cell tumor include the following:

- Three and six months postresection: history and physical examination, tumor markers (insulin) and CT/MRI.

- Long-term: history and physical examination with tumor markers every 6-12 months for years 1 to 3. Imaging studies are recommended only if clinically indicated.

\section{Conclusions}

Pancreatic beta cell tumors are a relatively rare cause of hypoglycemia. The suspicion of a probable insulinoma by the physician is important as the diagnosis of these tumors may be delayed up to 1-2 years and may be confused with other diseases such as neurological or psychiatric.

The diagnostic suspicion of an insulinoma is based on symptoms, and laboratory techniques usually confirm the diagnosis. The treatment, on the other hand, is usually surgery of the tumoral mass as complete as possible, including the primary tumor and metastases if present and possible. Imaging of the primary tumor location and the extent of the disease is needed for all phases of management of insulinomas, especially if they are malignant.

The development of new treatments based upon a better knowledge of the molecular pathways involved in tumorigenesis make the therapeutic future of these tumors promising, leading to a better prognosis in those with a more aggressive behavior.

On the other hand, the low incidence of these tumors makes especially important their management in specialized centers with experience and modern imaging and diagnostic techniques.

\section{Acknowledgement}

The authors want to thank Dr. Alberola and Dr.Rayon for the histological images lended.

\section{References}

Abellán, P., Cámara, R., Merino-Torres, JF., Pérez-Lázaro, A., del Olmo, MI., Ponce, JL., Rayón, JM., \& Piñón, F. Severe hypoglycemia after gastric bypass surgery for morbid obesisty. Diabetes Research and Clinical Practice, Vol. 79, No.1, (January 2008), pp. e7-e9, 0168-8227.

Anderson, M., Carpenter, S., Thompson, NW., Nostrant, T., Elta, G., \& Scheimann, JM. Endoscopic ultrasound is highly accurate and directs management in patients with neuroendocrine tumors of the pancreas. The American Journal of Gastroenterology, Vol.95, No.9, (April 2000), pp. 2271-2277, 0002-9270.

Arnold, A. (2009). Pathogenesis of Endocrine Tumors, In: Williams Textbook of Endocrinology, Kronenberg, H., Melmed, S., Polonsky, K., \& Larsen, R., pp. 1713-1720, Elsevier Saunders, 978-1-4160-2911-3, United States.

Assalia, A., \& Gagner, M. Laparoscopic pancreatic surgery for islet cell tumors of the pancreas. World Journal Surgery, Vol. 28, No.12, (December 2004), pp.1239-1247, 0364-2313. 
Brandi, ML., Gagel, R., Angeli, A., Bilezikian, JP., Beck-Peccoz, P. Bordi, C., Conte-Devolx, B., Falchetti, A., Gheri, RG., Libroia, A., Lips, CJ., Lombardi, G., Mannelli, M., Pacini, F., Ponder, BA., Raue, F., Skogseid, B., Tamburrano, G., Thakker, RV., Thompson, NW., Tomassetti, P., Tonelli, F., Wells, SA., \& Marx, SJ., Guidelines for diagnosis and therapy of MEN type 1 and type 2. The Journal of Clinical Endocrinology \& Metabolism, (August, 2001), Vol.86, No. 12, pp. 56-58, 0021-972X.

Cryer, P. (2009). Glucose Homeostasis and Hypoglycemia, In: Williams Textbook of Endocrinology, Kronenberg, H., Melmed, S., Polonsky, K., \& Larsen, R., pp. 15191550, Elsevier Saunders, 978-1-4160-2911-3, United States.

Gagel, R., \& Marx, S. (2009). Multiple Endocrine Neoplasia, In: Williams Textbook of Endocrinology, Kronenberg, H., Melmed, S., Polonsky, K., \& Larsen, R., pp. 17211762, Elsevier Saunders, 978-1-4160-2911-3, United States.

Gomez, JM., \& Soler, J.(2002) Prueba de ayuno, In: Manual de Pruebas Funcionales de Endocrinología, Gomez, JM \& Soler, J, pp.107-109, Septem Ediciones, 84-95687-37-2, Spain.

Hirshberg, B., Livi, A., Batlett, DL., Libutti, SK.., Alexander, HR., Doppman, MC., Skarulis, MC., \& Gorden, P. Forty-Eight-Hour Fast: The Diagnostic Test for Insulinoma. The Journal of Clinical Endocrinology \& Metabolism, Vol.85, No.9, (June 2000), pp.32223226, 0021-972X.

Hirshberg, B., Cochran, C., Skarulis, MC., Libutti, SK., Alexander, HR., Wood, BJ., Hang, R., Kleiner, DE., \& Gorden, P. Malignant insulinoma: spectrum of unusual clinical features. Cancer, Vol. 104, No.2, (2005), pp.264-272, 1097-0142.

Imamura, M., Hattori, Y., Nishida, O., Honda, T., Shimada, Y., \& Miyahara, T. Unresponsiveness of insulinoma cells to secretin: significance of the secretin test in patients with insulinoma. The Journal of Clinical Endocrinology and Metabolism. Vol. 74, (1992), pp.467-473, 0021-972X.

Jensen, R.(2002), Tumores endocrinos del tubo digestive y del páncreas, In: Harrison: Principios de Medicina Interna, Braunwald, E., Fauci, A., Kasper, D., Hauser, D., Longo, D., \& Jameson, L., pp.701-714, Mc Graw Hill, 84-486-0665-5, Spain.

Jonkers, YMH., Ramaekers, FCS., \& Speel, EJM. Molecular alterations during insulinoma tumorigenesis. Biochimica et Biophysica Acta, 1775, (May 2007), pp 313-332, 01674838, 0378-1119.

Marazuela, M., Martin-Perez, E., Larrañaga, E., Caniego, JL., Lopez-Iglesias, M., \& GómezPan, A. Diagnóstico y tratamiento del insulinoma: nuestra experiencia en 10 casos. Endocrinología y Nutrición, Vol.52, No.7, pp.338-343, 1575-0922

Klimstra, D., Modlin, I., Coppola, D., Lloyd, R., \& Suster, S. The pathologic classification of Neuroendocrine tumors: A review of Nomenclature, Grading and Staging Systems. Pancreas, Vol.39, No.6, (August 2010), pp.707-712, 0885-3177.

Komminoth, P., Perren, A., Öberg, A., Rindi G., Heitz, U., \& Klöppel G. (2004). Insulinoma, In: World Health Classification of Tumours. Pathology and genetics of tumours of endocrine organs, DeLellis, RA., Lloyd, RV., \& Heitz, PU., pp.183-187, IARC press, 928322416 7, Lyon.

Koopmans, K., Neels, O., Kema, I., Elsinga, P., Sluiter, W., Vanghillewe, K., Brouwers, A., Jager, P., \& de Vries, E. Improved Staging of Patients with carcinoid and islet cell tumors with 18F-dihydroxy-phenyl-alanine and 11C-5-hydroxy-tryptophan 
positron emission tomography. Journal of Clinical Oncology, Vol.26, No.9, (March 2008), pp. 1489-1495, 0732-183X.

Kouvaraki, M., Ajani, J., Hoff, P., Wolff, R., Evans, DB., Lozano R., \& Yao, C. Fluouracil, doxorubicin and streptozocin in the treatment of patients with locally advanced and metastatic pancreatic endocrine carcinomas. Journal of Clinical Oncology. Vol. 22, No.23, (December 2004), pp.4762-4771, 0732-183X.

Kouvaraki, MA., Shapiro, SE., Cote, GJ, Lee, JE., Yao, JC., Waguespack, SG., Gagel, RF., Evans, DB., \& Perrier, ND. Management of pancreatic endocrine tumors in multiple endocrine neoplasia type 1. World Journal Surgery, Vol.30, No 5, (April 2006), pp.643-653, 0364-2313.

Kulke, M., Anthony, L., Bushnell, D., de Herder, W., Goldsmith, S., Klimstra, D., Marx, S., Pasieka, J., Pommier, R., Yao, J., \& Jensen, R. NANETS Treatment Guidelines: Welldifferentiated Neuroendocrine Tumors of the Stomach and Pancreas. Pancreas, Vol. 39, No.6, (August 2010), pp. 735-752, 0885-3177.

National Comprehensive Cancer Network (NHHN, 2010). NCCN Clinical Practice Guidelines in Oncology: Neuroendocrine Tumors. V.I.2010.

Placzkoski, KA., Vella, A., Thompson, GB., Grant, CS., Reading, CC., Charboneau, JW., Andrews, JC., Lloyd, RV., \& Service, FJ. Secular Trends in the presentation and management of functioning insulinoma at the Mayo Clinic, 1987-2007. The Journal of Clinical Endocrinology and Metabolism, Vol. 94, No.4, (April 2009), pp. 1069-1073, 0021-972X.

Plockinger, U., Wiedenmann, B. Neuroendocrine tumors. Biotherapy. Best Practice $\mathcal{E}$ Research: Clinical Endocrinology \& Metabolism.Vol.21, No.1, (March 2007), pp. 145162,1521-690X

Ramos-Prol, A., del Olmo-Garcia, MI., Pérez-Lázaro, A., Caballero-Soto, M., Argente-Pla, A., León de Zayas, B., \& Merino-Torres, JF. Metabolic acidosis as a complication of intravenous dextrose administration in a patient with insulinoma. Endocrine, Vol 38, (October 2010), pp.402-405, 0969-711X.

Raymond, E., Dahan, L., Raoul, JL., Bang, YJ., Borbath, I., Lombard-Bohas, C., Valle, J., Metrakos, P., Smith, D., Vinik, A., Chen, JS., Hörsch, D., Hammel, P., Wiedenmann, B., Van Custem, E., Patyna, S., Ray Lu, D., Blanckmeister, C., Chao, R., \& Ruszeniewski, P. Sunitinib Malate for the Treatment of Pancreatic Neuroendocrine Tumors. The New England Journal of Medicine, Vol. 364, No.6, (February 2011), pp. 501-513, 0028-4793.

Rockall, AG., \& Reznek, RH. Imaging of neuroendocrine tumours (CT/MR/US). Best Practice \& Research: Clinical Endocrinology E Metabolism.Vol.21,No.1, (March 2007), pp. 141-148,1521-690X

Semelka, RC., Custodio,CM., CemBalci, BN., \& Woosly, JC. Neuroendocrine tumors of the pancreas: spectrum of appearances on MRI. Journal of Magnetic Resonance Imaging. Vol.11, No.2, (February 2000), pp.141-148, 1053-1807.

Service, FJ., McMahon, MM., O'Brien, PC., \& Ballard, DJ., Functioning insulinoma: incidence, recurrence, and long term survival of patients: a 60-year study. Mayo Clinic Proceedings, Vol.66, (July 1991), pp. 711-719, 0025-6196.

Service, FJ., O'Brien, PC., Kao, PC., \& Young, WF. C-peptide suppression test: effects of gender, age and body mass index; implications for the diagnosis of insulinoma. The Journal of Clinical Endocrinology and Metabolism. Vol,74, (1992), pp.204-210, 0021-972X. 
Service, FJ. Diagnostic approach to adults with hypoglycemic disorders. Endocrinology and metabolism clinics of North America. Vol. 28, No.3, (September 1999), pp. 519-532, 0889-8529.

Sherman, S., Gagel, R. (2002). Trastornos que afectan a sistemas endocrinos múltiples, In: Harrison: Principios de Medicina Interna, Braunwald, E., Fauci, A., Kasper, D., Hauser, D., Longo, D., \& Jameson, L., pp.2555-2563, Mc Graw Hill, 84-486-0665-5, Spain.

Sheth, S., Hruban, R., \& Fishman, E. Helical CT of islet cell tumors of the pancreas: Typical and Atypical Manifestations. American Journal of Roetgenology. Vol. 179, N0.3, (September, 2002), pp. 725-730, 0361-803X.

Starke, A., Saddig, C., Mansfeld, L., Koester, R., Tschahargane, C., Czygan, P., \& Goretzki, P. Malignant metastasic insulinoma: postoperative treatment and follow-up. World Journal of Surgery. Vol. 29, (May 2005), pp. 789-793, 0364-2313.

Steinmuller, T., Kianmanesh, R., Falconi, M., Scarpa, A., Taal, B., Kwekkeboom, D., Lopes, JM., Perren, A., Nikou, G., Yao, J., Delle Fave, GF., O'Toole, D., \& other Frascati Conference Participants. Consensus guidelines for the management of patients with liver metastases from digestive (neuro)endocrine tumors: foregut, midgut, hindgut, and unknown primary. Neuroendocrinology, Vol. 87, (November 2008), pp.47-62, 1423-0194.

O' Toole, D., Ruszniewski, P. Chemoembolization and other ablative therapies for liver metastases of gastrointestinal endocrine tumours. Best Practice $\mathcal{E}$ Research: Clinical Endocrinology \& Metabolism.Vol.19, No.4, (August 2005), pp. 585-594,1521690X

Thoeni, R., Mueller-Lisse, UG., Chan R., Ky Do, R., \& Shyn, PB. Detection of small, functional islet cell tumors in the pancreas: selection of MR imaging sequences for optimal sensitivity. Radiology, 214, (February 2000), pp. 483-490, 0033-8419.

Thompson, GB., Service, FJ., Andrews, JC., Lloyd, RV., Natt, N., van Heerden, JA., \& Grant, CS. Noninsulinoma pacreatogenous hypoglycemia syndrome: an uptake in 10 surgically treated patients. Surgery, Vol. 128, No.6, pp.937-944, ISSN.

Vaidakis, D., Karoubalis, J., Pappa, T., Piaditis, G., \& Zografos, G. Pancreatic insulinoma: current issues and trends. Hepatobiliary \& Pancreatic Diseases International, Vol.9, No.3, (June 2010), 1499-3872.

Vinik, A., Woltering, E., Warner, R., Caplin, M., O'Dorisio, T., Wiseman, G., Coppola, D., \& Go, VL. NANETS Consensus Guidelines for the diagnosis of Neuroendocrine Tumor. Pancreas, Vol.39, No.6, (August 2010), pp. 713- 734, ISSN 0885-3177.

Virgolini, I., Traub-Weidinger, T., Decristoforo C. Nuclear medicine in the detection and management of pancreatic Islet-cell tumours. Best Practice $\mathcal{E}$ Research: Clinical Endocrinology \& Metabolism.Vol.19,No.2, (June 2005), pp. 213-227,1521-690X

Yao, J., Phan, A., Chang, D., Wolff, R., Hess, K., Gupta, S., Jacobs, C., Mares, J., Landgraf, A., Rashid, A., \& Meric-Bernstam, F. Efficacy of RAD001 (everolimus) and Octeotride LAR in Advanced-Low-to intermediate -Grade Neuroendocrine tumors: results of phase II study. Journal of Clinical Oncology, Vol.26, No.26, (September 2008), pp. 4311-4319, 0732-183X. 


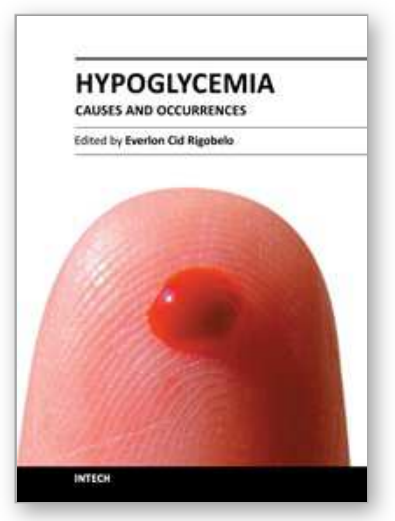

\author{
Hypoglycemia - Causes and Occurrences \\ Edited by Prof. Everlon Rigobelo
}

ISBN 978-953-307-657-7

Hard cover, 238 pages

Publisher InTech

Published online 10, October, 2011

Published in print edition October, 2011

Glucose is an essential metabolic substrate of all mammalian cells being the major carbohydrate presented to the cell for energy production and also many other anabolic requirements. Hypoglycemia is a disorder where the glucose serum concentration is usually low. The organism usually keeps the glucose serum concentration in a range of 70 to $110 \mathrm{~mL} / \mathrm{dL}$ of blood. In hypoglycemia the glucose concentration normally remains lower than $50 \mathrm{~mL} / \mathrm{dL}$ of blood. This book provides an abundance of information for all who need them in order to help many people worldwide.

\title{
How to reference
}

In order to correctly reference this scholarly work, feel free to copy and paste the following:

M. Isabel del Olmo, J. Francisco Merino-Torres, J. Luis Ponce and Angel Moya (2011). Pancreatic Beta Cell Tumors, Hypoglycemia - Causes and Occurrences, Prof. Everlon Rigobelo (Ed.), ISBN: 978-953-307-657-7, InTech, Available from: http://www.intechopen.com/books/hypoglycemia-causes-and-occurrences/pancreaticbeta-cell-tumors

\section{INTECH}

open science / open minds

\section{InTech Europe}

University Campus STeP Ri

Slavka Krautzeka 83/A

51000 Rijeka, Croatia

Phone: +385 (51) 770447

Fax: +385 (51) 686166

www.intechopen.com

\section{InTech China}

Unit 405, Office Block, Hotel Equatorial Shanghai

No.65, Yan An Road (West), Shanghai, 200040, China

中国上海市延安西路65号上海国际贵都大饭店办公楼405单元

Phone: +86-21-62489820

Fax: +86-21-62489821 
(C) 2011 The Author(s). Licensee IntechOpen. This is an open access article distributed under the terms of the Creative Commons Attribution 3.0 License, which permits unrestricted use, distribution, and reproduction in any medium, provided the original work is properly cited. 